www.nature.com/pj

\title{
REVIEW
}

\section{Characteristics of bacterial biofilm associated with implant material in clinical practice}

\author{
Venkatesan Nandakumar $^{1}$, Samuel Chittaranjan ${ }^{2}$, Valikapathalil Mathew Kurian ${ }^{3}$ and Mukesh Doble ${ }^{1}$ \\ Colonization of bacteria around native host cells or polymeric implant surfaces results in a dense growth on the surface, which \\ leads to infection. The change of a bacterium from a motile planktonic to a nonmotile long chain of growing cells is a complex, \\ regulated process that depends on several factors. The probability of a biofilm-related infection occurrence is between 65 and \\ $80 \%$. This review critically evaluates the mode of biofilm formation on native tissues and orthopedics, dental, cardiac, and \\ urological implants and vascular grafts. The combination of biochemical advancements with conventional microbiological \\ techniques and the use of radio-labeled monoclonal antibodies in imaging techniques, with recent developments in the \\ detection of these biofilm in vivo, would help in designing biomaterials that prevent bacterial adhesion and biofilm formation, \\ and dislodge the formed biofilm, thereby accelerating the product development phase.
}

Polymer Journal (2013) 45, 137-152; doi:10.1038/pj.2012.130; published online 11 July 2012

Keywords: antimicrobial resistance; cardiology; computational approach; implants; material design; orthopedics; quorum sensing

\section{INTRODUCTION}

A medical biofilm is a solid aggregate of microbial cells with altered phenotypes and unique architecture attached to a surface and to each other. They are distinctly different from those encountered in the marine and industrial sectors. ${ }^{1}$ The formation of these biofilms is determined by the type of organisms, availability of nutrients and the characteristics of substrate to which they adhere. Implant-associated biofilms cause infection and interrupt the proper functioning of the device to which it is formed. The probability of occurrence of an infection caused by these bacterial or fungal biofilms is between 65 (Center for Disease Control and Prevention) to 80\% (National Institute of Health). The urinary tract, respiratory tract, bloodstream and surgical wound sites are the major sites of nosocomial infection. Approximately $95 \%$ of urinary tract infections (UTIs) are associated with urinary stent and catheter tubes; $87 \%$ of bloodstream infections are associated with intravascular devices, including pacemakers, implantable cardioverter defibrillators, left ventricular assist devices and prosthetic vascular grafts; and $86 \%$ of pneumonia are associated with mechanical ventilation. ${ }^{2}$

From polymers to ceramics, many different types of materials are used in medical devices. These synthetic materials, which replace the body parts functionally and structurally, are termed as biomaterials. Although resorbable materials are widely considered for most implants, the problem of bacterial adhesion and biofilm formation remains unaddressed in most situations. Additionally, the problems and the severity of infection varies depending upon the location of the device and the duration of implant. The transition of the microorganisms from planktonic to biofilm state is a complex and a highly regulated process. ${ }^{3}$ Bacterial cells make up between 2 and $15 \%$ of the total biofilm mass, and the rest is mostly water. ${ }^{4}$ The implant surface serves as a substrate for the formation of biofilms. Deposition of the host-conditioning film onto the surface of a medical device occurs immediately after the placement of the device (Figure 1). This results in an irreversible attachment of bacteria due to the secretion of exopolysaccharides (EPS), leading to the formation of a base film. They then multiply and form a surface film, which is then free to float and spread downstream, thereby inducing a significant increase in the morbidity rate.

The physico-chemical properties of the implant surface, the characteristics of the organism and the environment in which the implant is placed determines the extent of a biofilm (Figure 2). The duration of the implant also determines the extent of the biofilm. The link between these factors and the ease of formation of biofilm leading to disease in a human host needs to be understood, to aid the patients therapeutically. Implant-associated infections are generally classified, on the basis of the onset of infection, as early (less than 2 weeks), delayed (2-10 weeks) or late (greater than 10 weeks).$^{5-7}$ In addition, based on the route of infection, they are classified as perioperative (bacterial colonization at the time of surgery), ${ }^{8}$ contiguous (through wound contamination) ${ }^{9}$ or hematogenous (spread of bacteria through the blood and lymph nodes). ${ }^{10}$ The sources of infection include skin, dental, respiratory and urinary tracts. ${ }^{11}$

${ }^{1}$ Department of Biotechnology, Indian Institute of Technology Madras, Chennai, India; ${ }^{2}$ Department of Orthopedics, Christian Medical College, Vellore, India and ${ }^{3}$ Institute of Cardiovascular Diseases, Madras Medical Mission, Chennai, India

Correspondence: Professor M Doble, Department of Biotechnology, Indian Institute of Technology Madras, No. 209, Chennai, Tamil Nadu 600 036, India.

E-mail: mukeshd@iitm.ac.in

Received 10 February 2012; revised 17 April 2012; accepted 26 April 2012; published online 11 July 2012 


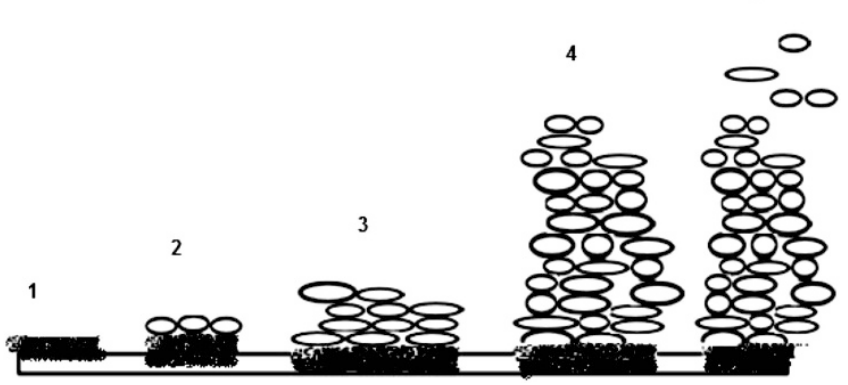

Figure 1 Various stages in the formation of a biofilm. (1) Deposition of host protein (conditioning layer); (2) primary attachment of single cells (mediated by cell surface adhesins including polysaccharides and pili); (3) formation of a micro-colony; (4) maturation of the biofilm (mediated by cell signaling molecules including auto-inducers); (5) detachment of cells.

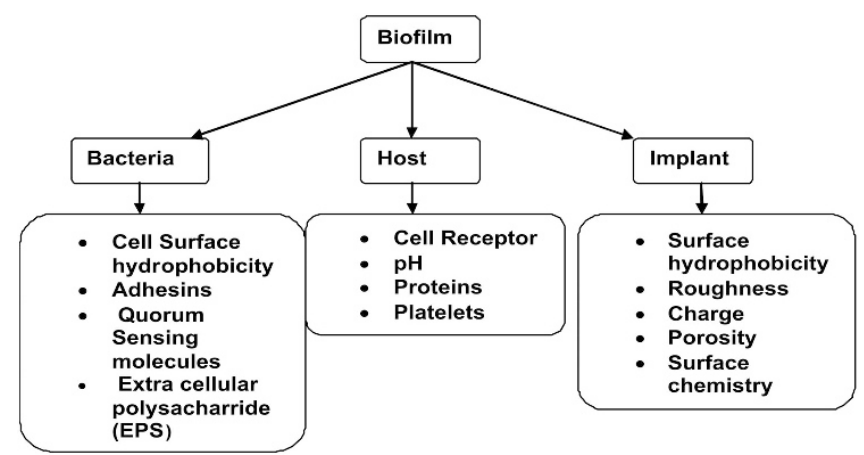

Figure 2 Factors affecting biofilm formation.

With the rise in the number of implant-dependent surgeries and biofilm-associated complications, there is a need to counteract and address this phenomenon. This need has led to various approaches to elucidate the etiology and pathogenesis of the infection. These approaches include the following: (i) identify and fingerprint bacterial strains, (ii) determine the origin of the infections, (iii) assess its clinical significance, (iv) understand the phylogeny and (v) decipher the mechanism through which new strains emerge. ${ }^{12}$ These implants always pose a serious risk factor for the hematogenous seeding of infections throughout the lifetime of the device. There are situations in which a biofilm is formed in different parts of the body, even in the absence of a foreign body, which is termed as nonimplant-associated biofilm.

This review critically evaluates the formation, characteristics, pathogenicity and the molecular genetics of both implant- and nonimplant-associated medical biofilm. The surface characteristics and properties of the implants that favor bacterial adhesion are also discussed.

\section{CHARACTERISTICS OF BIOFILMS AND THEIR VIRULENCE}

In addition to the live cells and dead cells, the biofilm matrix is composed of cell wall teichoic acids, DNA, $N$-acetyl-glucosamine and host products. ${ }^{13,14}$ The ability of bacteria to adhere and colonize onto the surface is an important feature in the pathogenesis of infection. ${ }^{1}$ The first step in the formation of a biofilm is the attachment of freefloating microorganisms onto the surface, followed by secretion of
EPS, rapid proliferation and aggregation of bacteria in the slime layer. These aggregates further differentiate into characteristic biofilms. ${ }^{15}$ Two important factors to be considered are (i) reversible bacterial adhesion, which is a nonspecific interaction between the bacteria, serum proteins and material surface, and (ii) irreversible specific ligand-receptor interaction between the bacteria and the adsorbed proteins and platelets. ${ }^{16}$ The surface of the microorganisms greatly influences their adhesion and the extent of biofilm formation. Reversible attachment depends on electrostatic, Van der Waals and other nonbonded forces of attraction between the microorganism and the surface. Cell surface hydrophobicity, and surface projections, including pili, fimbriae and glycocalyx, contribute to the irreversible attachment of the bacterium onto the polymeric surface. These appendages specifically facilitate the attachment of Gram-negative bacteria. ${ }^{17,18}$ Studies have reported that these appendages, especially the sex pili, have an important role in the formation of a micro colony. The absence of these appendages leads to the formation of a monolayer of cells. ${ }^{3}$

Gram-positive Enterococcus faecalis, Staphylococcus aureus, Staphylococcus epidermidis and Streptococcus viridan and Gramnegative Escherichia coli, Klebsiella pneumoniae, Proteus mirabilis and Pseudomonas aeruginosa are some of the bacterial strains commonly associated with device-associated infection. They form biofilms of single or multiple species, but with an increase in the in-dwelling time they develop into a multispecies biofilm. ${ }^{19}$ These bacterial cells aggregate and then detach from the biofilm as a result of cell division, thereby leading to systemic infection. ${ }^{20}$ The detachment of bacterial cells from the biofilm has an important role in the spread of the infection. Changes in the flow and direction results in hydrodynamic forces that removes a portion of the biofilm. ${ }^{21,22}$

Antimicrobial therapy against these biofilm is based on the conventional drugs tested against the free-floating bacterial strains. Although most of the antimicrobial drugs are active against these strains, the bacteria in the biofilm community are 1000-fold more resistant, and hence, these treatment strategies becomes less effective. ${ }^{23}$ Antimicrobial-resistant biofilm initiate the antigenic response in the host by stimulating antibody production, but these communities are still not affected by the host immunogenic response.

The presence of fluid-filled channels in a mature biofilm ensures transport of nutrients to cells that are located at the bottom of the film. ${ }^{24}$ Factors, including nutrient availability, the antimicrobials used $^{25}$ and the enzymes secreted by the bacterium, such as polysaccharide lyases and cell surface proteins, modulate and regulate the levels of adhesins. ${ }^{26}$ Over time, the bacteria mature and form more channels, so the distribution of live cells and dead cells within the biofilm matrix is unevenly spaced. ${ }^{27} \mathrm{~A}$ biofilm also produces persister cells, which accounts for $1 \%$ of the total bacterial cell population. These unique cells downregulate the biosynthetic genes, absorb the compounds slowly and survive the toxic effects of antimicrobial agents, which generally target the dividing cells. ${ }^{28}$

The growth of biofilms gives rise to small colony variants, a subpopulation of bacteria with diverse phenotypes. These variants either disseminate or accelerate the biofilm formation. ${ }^{29}$ In case of Pseudomonas aeruginosa, these variants provide increased resistance to oxidative stress. ${ }^{30}$ These variants are also found in the biofilms of Streptococcus pneumoniae, ${ }^{31}$ Staphylococcus epidermidis, ${ }^{32}$ Pseudomonas putida, ${ }^{33}$ Vibrio cholerae $^{34}$ and Vibrio vulnificus. ${ }^{35}$ Different variants of the same species are observed within infected individuals. A better understanding of the accumulation of these variants and their effect on the production of virulence factors is of clinical importance. 
There is a close linkage between the bacterial cell metabolism and its virulence factor synthesis. For example, in the case of Staphylococcus aureus, the metabolic regulatory proteins, CcpA and MgrA, are also the key regulators of its virulence factors. ${ }^{36,37}$ In case of Staphylococcus epidermidis, the formation of biofilm is the determinant of its virulence. ${ }^{38}$ SarZ, an important determinant of Staphylococcus epidermidis, biofilm formation greatly influences the expression of virulence genes that are responsible for its resistance against human antimicrobial peptides. ${ }^{39}$ Virulence factor encoding genes, usp and papC, are significantly expressed in the nonimmunocompromised Escherichia coli strains. ${ }^{40}$ GacA is a virulence factor in the case of Pseudomonas aeruginosa. GacA also has a key role in biofilm formation, which is regulated by a twocomponent regulatory system, namely GacA and GacS. ${ }^{41}$ EPS is an important virulence factor that is predominant in all biofilms. ${ }^{42}$ Streptococcus mutans has a key role in the EPS secretion in dental biofilms. This strain secretes three types of EPS (Gtfs), of which GtfB and $\mathrm{GtfC}$ are associated with bacterial adherence and the expression of virulence. $^{42}$

\section{MICROBIOLOGY OF INFECTED IMPLANTS}

Table 1 lists the type of material used in various implants, their immediate environment and the primary bacterial colonizers.

\section{Dental implant}

Dental implants are used to replace the teeth in case of edentulous and partial edentulous patients. Dental implants support single or several tooth restorations. Materials that are currently used for dental implants include metals, ceramic, polymer and vitreous carbon. A dental bacterial plaque is the colonization of bacterial cells around the tooth surface, crown or the implant. ${ }^{43}$ It is estimated that one million dental implants are placed annually, ${ }^{44}$ with a success rate reported as high as $90-95 \%$, despite bacterial infection. ${ }^{45}$ However, the prevalence of implant mucositis is reported to be greater than $60 \%{ }^{46}$ The various parts of the dental implant include an implant post, abutment and crown. The implants are classified as (i) endosteal (root form or plate form) implant, which is inserted directly into the jaw bone, (ii) subperiosteal implant, placed on and around the bone, (iii) transosteal implant, inserted through the chin and supported by a plate, and iv) temporary implant, used for temporary purpose. ${ }^{47}$ These implants are further classified based on the design. The epithelium of the oral environment is more permeable to salivary fluids and immunoglobulins. Saliva contains $10^{8}$ bacterial cells per milliliter along with proteins. ${ }^{48}$ Another characteristic feature that restricts the use of most biomaterials discussed here is the ultramicroscopic hemidesmosomes structures found in the junctional epithelium - the tooth interface, whose integrity is required for proper functioning of the implant. ${ }^{47}$

Peri-implant mucositis, is an inflammation of the soft tissue due to the colonization of Capnocytophaga ochracea, Neisseria mucosa, Porphyromonas gingivalis, Prevotella nigrescens, Fusobacterium sp. and actinomycetes. ${ }^{49}$ Peri-implantitis is another oral biofilmmediated problem resulting in significant bone loss and filled with inflammatory tissues (Figure 3), which are primarily caused by Porphyromonas gingivalis, Tannerella forsytha, Prevotella intermedia, Fusobacterium ssp., Streptococcus sanguinis, Streptococcus gordonii, Veillonella parvula and actinomycetes. ${ }^{49}$ Intact plaque from periimplant is composed of Coccoid cells and Spirochetes, ${ }^{50}$ with highly pathogenic Staphylococcus aureus, Pseudomonas sp. and Enterobacteria in the saliva. ${ }^{51}$
Gram-negative anaerobes are predominant in the titanium periimplant and their number increases with increasing depth. ${ }^{52} \mathrm{~A}$ comparison of successful and failed implants indicates that in most cases, Gram-negative anaerobic rods, in particular Fusobacterium sp. and Prevotella intermedia, are predominant and abundant, whereas even the successful implant contains very low counts of Gram-positive cocci and few rods. ${ }^{53}$ Gram-negative anaerobic rods, including blackpigmented organisms and surface translocators, are also reported with ceramic implants. ${ }^{54}$ Prevotella intermedia and Porphyromonas gingivalis have been reported in failed blade implants, ${ }^{55}$ and in a few cases, high counts of Staphylococcus sp., ${ }^{56}$ Bacteroidaceae and Aggregatibacter actinomycetemcomitans are found in the associated tissues. ${ }^{57}$ Staphylococcus aureus and enteric, and Escherichia coli and Enterobacter cloace, are also reported in partial dentate cases. ${ }^{58}$ The lack of differences between the microbial populations suggests that the disease evolves from mucositis to peri-implantitis. ${ }^{59}$

\section{Orthopedic implants}

Orthopedic implants can be broadly classified as shoulder, elbow, hip, knee and spine implants. Some of the materials that are widely used include stainless steel, titanium alloys, tantalum, titanium, cobalt chromium alloys and polyethylene. Most bacteria isolated from orthopedic implants are not susceptible to common antibiotics, even in the sessile form. ${ }^{60}$ Orthopedic implant-related infections are of great importance because of their significant morbidity rate. Freefloating species binds to the native or prosthetic joint and transforms into small colony variants. This results in additional modification that results in a mature, antimicrobial-resistant biofilm.

Staphylococcus aureus and methicillin-resistant Staphylococcus aureus are the predominant bacteria associated with most of the orthopedic implant-related infections, ${ }^{61}$ whereas in prosthetic joints, low-grade infection, which commences from few months to a year after implantation, is caused by coagulase negative Staphylococci and Propionibacterium acnes. ${ }^{62}$ The risk of infection is higher in case of knee joints than in the case of hip or shoulder prosthesis followed by fracture plates (Figure 4).

Hematogenous Staphylococcus aureus is more commonly associated with patients suffering from rheumatoid arthritis. ${ }^{63}$ Most of the hip joint infections are of bacterial origin. Coagulase negative Staphylococcus aureus is the predominant pathogen associated with the perihip prosthetic joint, and the other Gram-positive agents include Streptococcus pyogenes, Enterococcus faecalis and Corynebacteria species. Anaerobic bacteria, Propionibacterium acnes, Peptococcus asaccharides, Peptococcus magnus and Peptostreptococcus magnus account for $12 \%$ of hip periprosthetic infection. A group of enteric is the causative agent for arthritis and joint infection. ${ }^{64}$ Approximately $50 \%$ of the hip and knee joint infections are caused by Staphylococcus epidermidis. ${ }^{65}$

Bacterial attachment and replication is very high on polymethylmethacrylate. ${ }^{66}$ The adherence of Mycobacterium tuberculosis to stainless steel and titanium is poor, which make them a better substitute in the case of spinal tuberculosis. ${ }^{67}$

\section{Cardiac implants}

Prosthetic valves, ventricular-assisted devices and coronary stents are some of the predominant cardiac implants. The environment of most of these implants is blood. Coagulase-negative Staphylococcus aureus is a primary causative agent in the case of heart valves and ventricularassisted devices. Staphylococcus aureus, Streptococcus sp., Gram-negative Bacilli, Enterococci, Pseudomonas aeruginosa are other colonizers found in these implants. ${ }^{68}$ CoNS, a normal skin flora, also adhere 
Table 1 List of materials used and their corresponding environment and primary colonizers

\begin{tabular}{|c|c|c|c|}
\hline Parts & Materials & Environment & Colonizers \\
\hline \multicolumn{4}{|l|}{ Catheters } \\
\hline Central venous catheters & Polyurethane 214 & Blood & $\begin{array}{l}\text { Staphylococcus epidermidis, }{ }^{215} \text { Staphylococcus aureus, } \\
\text { Pseudomonas aeruginosa, Klebsiella pneumoniae and } \\
\text { Enterococcus faecalis }^{214}\end{array}$ \\
\hline Hemodialysis catheters & PTFE $^{216}$ & Blood & $\begin{array}{l}\text { Staphylococcus aureus and few Gram-negative } \\
\text { anaerobes } \\
216\end{array}$ \\
\hline Pulmonary artery catheters & Polyurethane & Blood & $\begin{array}{l}\text { Coagulase-negative Staphylococci, Enterobacter } \\
\text { cloacae, Serratia marcescens, Aeromonas hydrophila, } \\
\text { Pseudomonas aeruginosa, Acinetobacter } \\
\text { cakoaceticus }^{217}\end{array}$ \\
\hline Urinary catheters & Silicone, polyurethane, ${ }^{81,218}$ silicone $^{81}$ & Urine & $\begin{array}{l}\text { Escherichia coli, }{ }^{89} \text { Enterococcus faecalis, Enterococcus } \\
\text { faecium, } 90 \text { Proteus mirabilis } 81,184\end{array}$ \\
\hline Peritoneal dialysis & Silicone 219 & $\begin{array}{l}\text { Blood, fluid and } \\
\text { dissolved solids }\end{array}$ & Staphylococcus epidermidis, Staphylococcus aureus 219 \\
\hline Enteral feeding tubes & Poly vinyl chloride and polyurethane $e^{220}$ & Fluids & $\begin{array}{l}\text { Cronobacter sakazakii, Salmonella serovars, } \\
\text { Enterobacteriaceae, Acinetobacter spp. }{ }^{220}\end{array}$ \\
\hline Gastrostomy tubes & Silicone, polyurethane ${ }^{221}$ & Intestinal fluids & $\begin{array}{l}\text { Enterococci, Staphylococci, Escherichia coli, } \\
\text { Lactobacilli, Bacilli222 }\end{array}$ \\
\hline Endotracheal tubes & PVC, silicone, stainless steel 223 & $\begin{array}{l}\text { Oropharyngeal } \\
\text { secretions, air }\end{array}$ & Streptococcus sp., Prevotella sp., Neisseria sp. ${ }^{224}$ \\
\hline $\begin{array}{l}\text { Tracheostomy tubes } \\
\text { Implants }\end{array}$ & PVC, silicone 225 & Air & Staphylococcus epidermidis ${ }^{226}$ \\
\hline Spinal implant & Titanium, stainless steel 227 & Fluids & $\begin{array}{l}\text { Propionibacterium acnes and coagulase-negative } \\
\text { Staphylococci, }{ }^{168} \text { Mycobacterium tuberculosis }\end{array}$ \\
\hline Penile implant & Silicone 228 & Urine, fluids & Gram-positive rods, cocci $^{229}$ \\
\hline Breast implant & Silicone, polyurethane ${ }^{230}$ & Body fluids & $\mathrm{CoNS}^{231}$ \\
\hline \multicolumn{4}{|l|}{ Orthopedic prosthesis } \\
\hline Knee implant & $\begin{array}{l}\text { Femor: titanium, cobalt chromium alloys } \\
\text { Patella: polyethylene } \\
\text { Tibia: UHMWPE or PE with metal stem (tita- } \\
\text { nium, cobalt chromium alloys) }\end{array}$ & Blood, synovial fluid & $\begin{array}{l}\text { Staphylococcus aureus, Staphylococcus } \\
\text { epidermidis. }{ }^{232}\end{array}$ \\
\hline Hip prosthesis & $\begin{array}{l}\text { Acetabulum: UHMWPE, }{ }^{233} \text { cobalt chromium, } \\
\text { aluminum oxide } \\
\text { Femoral head: cobalt chromium, aluminum } \\
\text { oxide } \\
\text { Stem: stainless steel }\end{array}$ & $\begin{array}{l}\text { Synovial fluid, } \\
\text { blood }\end{array}$ & CoNS, Staphylococcus aureus ${ }^{234}$ \\
\hline Dental implants & $\begin{array}{l}\text { Crown: porcelain, }{ }^{235} \text { metal (gold) } \\
\text { Abutment: titanium, }{ }^{235} \text { zirconia, }^{235} \text { PTFE. }{ }^{236} \\
\text { Implant: titanium }{ }^{237}\end{array}$ & $\begin{array}{l}\text { Fluids, immunoglo- } \\
\text { bulins, blood }\end{array}$ & Gram-negative anaerobic rods ${ }^{52,54}$ \\
\hline Defibrillators & & Fluids & Staphylococcus aureus, ${ }^{238}$ Staphylococcus epidermidis \\
\hline \multicolumn{4}{|l|}{ Devices } \\
\hline Biliary stent & $\begin{array}{l}\text { Polytetrafluorethylene, polyethylene, } \\
\text { polyurethane }^{239}\end{array}$ & Biliary drains & Escherichia coli, Enterococcus faecalis ${ }^{239}$ \\
\hline IUD & Copper 240 & Endometrial cavity & $\begin{array}{l}\text { Staphylococcus aureus, Staphylococcus epidermidis, } \\
\text { Pseudomonas aeruginosa, Escherichia coli, Neisseria } \\
\text { gonorrhoeae } 240\end{array}$ \\
\hline Mechanical heart valves & $\begin{array}{l}\text { Cage: titanium and cobalt alloys } \\
\text { Occluder: silicone rubber and pyrolytic carbon } \\
\text { Sewing ring: PET, PTFE, PP241 }\end{array}$ & Blood & $\begin{array}{l}\text { Staphylococcus aureus, Pseudomonas aeruginosa, } \\
\text { Staphylococcus. epidermidis }\end{array}$ \\
\hline Vascular grafts & PTFE, Dacron ${ }^{76}$ & Blood & $\begin{array}{l}\text { Staphylococcus aureus, Staphylococcus epidermidis } \\
\text { MRSA }^{79}\end{array}$ \\
\hline Coronary stents & $\begin{array}{l}316 \mathrm{~L} \text { Stainless steel, }{ }^{242} \text { cobalt chromium } \\
\text { alloy, }{ }^{243} \text { tantallum, }{ }^{242} \text { pure } \mathrm{Fe}^{244}\end{array}$ & Blood & Escherichia coli, Staphylococcus aureus \\
\hline Intraoccular lens & Silicone, PMMA, acrylic 245,246 & Fluid & $\begin{array}{l}\text { Staphylococcus aureus, }{ }^{245} \text { Staphylococcus } \\
\text { epidermidis } 246\end{array}$ \\
\hline Intracranial pressure devices & Silicone $e^{247}$ & Cerebrospinal fluid & CoNS, Propionibacterium acnes ${ }^{247}$ \\
\hline Suture material & Polyglycolic acid, polyglactin, cat gut ${ }^{248}$ & & Staphylococcus aureus, Enterococcus faecalis 249,250 \\
\hline
\end{tabular}

Abbreviations: CoNS, coagulase-negative Staphylococcus aureus; MRSA, methicillin-resistant Staphylococcus aureus; PE, polyethylene; PET, polyethylene terephthalate; PMMA, polymethylmethacrylate; PP, polypropylene; PTFE, polytetrafluoroethylene; PVC, polyvinyl chloride; UHMWPE, ultra high-molecular weight polyethylene. 


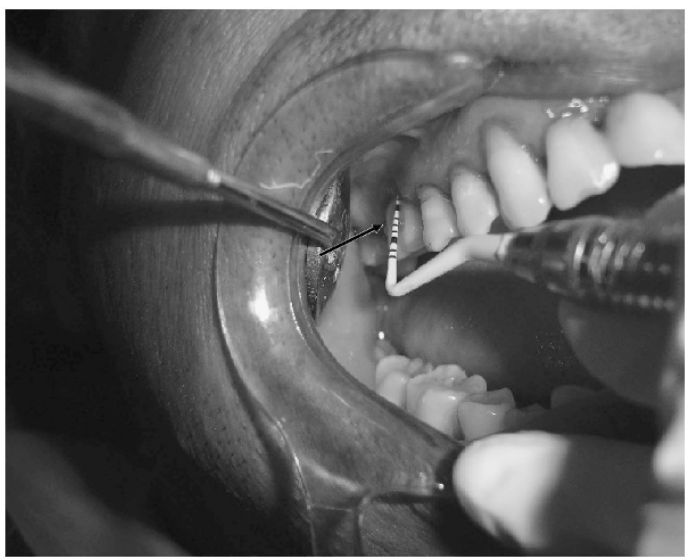

Figure 3 Peri-implantitis indicated by bleeding in a male. A full color version of this figure is available at Polymer Journal online.

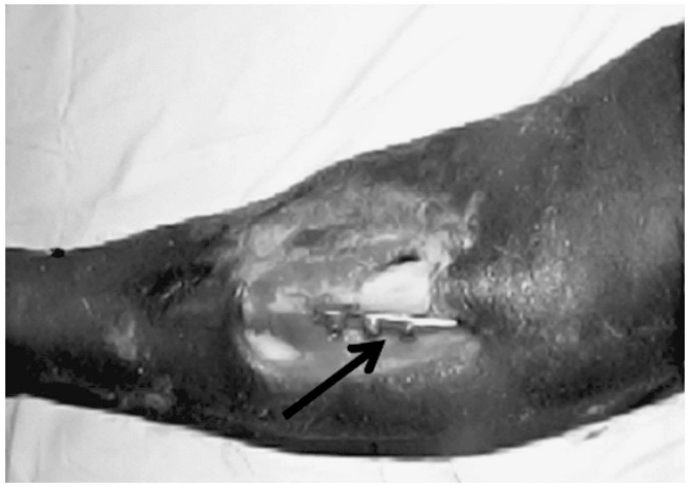

Figure 4 Infected fracture plate of a male-post-internal fixation. A full color version of this figure is available at Polymer Journal online.

to the medical devices and to the adjacent tissues, predominantly to fibronectin. ${ }^{69}$ Staphylococcus aureus, which is a nasopharyngeal and nosocomial pathogen, produces multiple toxins that degrade the tissues and stimulate the host immune response. ${ }^{68}$

Mechanical prosthesis and bioprosthesis are used extensively to replace heart valves. The placement of these implants result in physical abrasions of the tissues, resulting in the accumulation of platelets and fibrin. This accumulation serves as a substrate for bacterial colonization. ${ }^{69}$ The predominant colonizers include Staphylococcus, Streptococcus sp., Gram-negative rods and Enterococci. ${ }^{70}$ In case of prosthetic valves, adherence of bacteria is in the following order: Staphylococcus aureus, Pseudomonas aeruginosa and Staphylococcus epidermidis. ${ }^{71}$ The risk of endocarditis (Figure 5) is similar for mechanical or bioprosthetic valves. ${ }^{72,73}$ Prosthetic valves infected with Streptococcus are treated with intravenous or intramuscular antibiotics (parenteral antibiotics). ${ }^{74}$ Infection other than Streptococcal warrants a valve replacement procedure. ${ }^{75}$

\section{Vascular graft}

Prosthetic vascular grafts are used to replace blocked or nonfunctional blood vessels to ensure the proper flow of blood. The grafts are classified as either small- or large-diameter vascular grafts. The grafts are primarily made of expanded polytetrafluoroethylene (ePTFE) and Dacron. ${ }^{76}$ The likelihood of infection in case of a prosthetic vascular

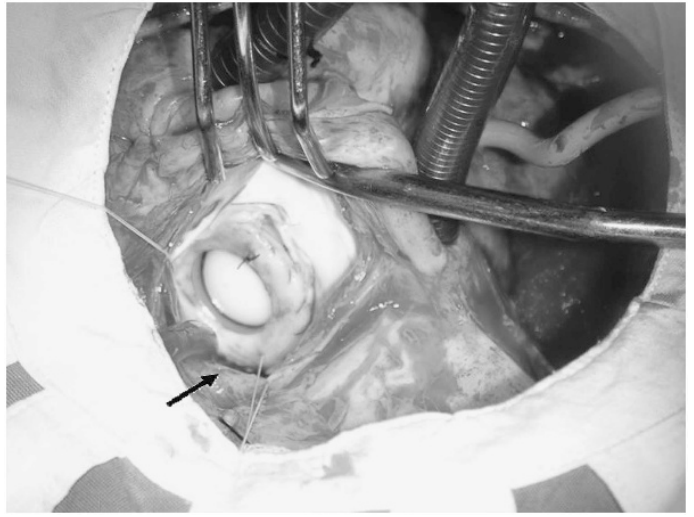

Figure 5 Prosthetic valve endocarditis with a paravalvar leak. A full color version of this figure is available at Polymer Journal online.

graft is between 2 and $6 \% .{ }^{77}$ Adherence of Staphylococcus aureus, mucin- and nonmucin-producing Staphylococcus epidermidis, and Escherichia coli is higher in knitted Dacron and ePTFE vascular grafts. Adherence of Staphylococcus epidermidis to knitted Dacron and ePTFE significantly increases with mucin production. ${ }^{76}$ Adherence of Escherichia coli is lower in ePTFE than that of Staphylococcus epidermidis in ePTFE. Nevertheless, no significant difference was observed between the adherences of Escherichia coli and Staphylococcus epidermidis to Dacron. In case of vascular graft infection, the colonization of Staphylococcus epidermidis is not easily detected. ${ }^{78}$ Despite successful treatment with antibiotics, methicillinresistant Staphylococcus aureus is also reported in vascular graft infections. ${ }^{79}$ Although it is believed that the translocation of bacterial cells along the pores of the graft has an important role in infection, methicillin-resistant Staphylococcus aureus and Escherichia coli do not exhibit such a behavior. ${ }^{80}$

\section{Urological implants}

Major urological implants include permanent and temporary ureteral stents, penile implants and catheter tubes. The primary function of a stent is to aid the proper flow of urine and to reduce early (approximately $<1$ week) and late ( $>1$ month) complications due to encrustation and bacterial adhesion. Synthetic polymers, which include polyurethane, silicone, polyisobutylene, self-reinforced polylactic acid, self-reinforced polyglycolic acid, polystyrene, polymethylmethacrylate and poly (2-hydroxyethyl methacrylate), have been tested as ureteral stents. Out of these, polyurethanes are the most widely used material in ureteral stents because they are more biocompatible than the other polymers. ${ }^{81}$ The colonization of Gram-negative pathogens is the main issue related to infection in ureteral stents (Figure 6). Hydrophilic Escherichia coli exhibit lower adhesion, whereas hydrophobic Enterococcus faecalis exhibit higher adhesion onto this partially hydrophobic surface. ${ }^{81}$ Despite postoperative antimicrobial treatment, in most cases, small and large microcolony biofilms are formed, of which $77 \%$ are Grampositive cocci, $15 \%$ are Gram-negative rods and $8 \%$ are Candida. ${ }^{82}$ The colonization of bacteria onto ureteral stents is $100 \%$ in case of patients with permanent stents and $69 \%$ in stents that remain in the body for a few weeks to few months. ${ }^{83}$

Adherence of Staphylococcus epidermidis ${ }^{84}$ and Staphylococcus sp. ${ }^{85}$ onto silicone elastomer in penile implants is well documented. Biofilm formation has been observed even in noninfected healthy 


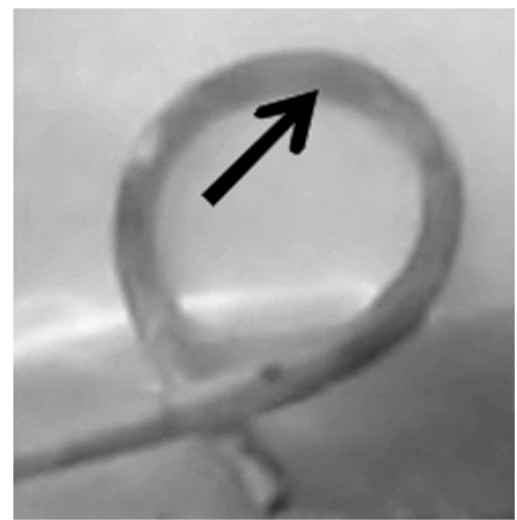

Figure 6 Severely encrusted double j-pigtail ureteral stent. A full color version of this figure is available at Polymer Journal online.

individuals with penile implants. ${ }^{86}$ Catheters are small plastic tubes that help to drain urine from the bladder. The colonization of bacteria in the bladder in the case of UTI follows growth, maturation and detachment within the urinary tract. This leads to the formation of biofilms on the drainage catheters. ${ }^{87,88}$ The majority of the infection is due to uropathogenic Escherichia coli, ${ }^{89}$ whereas $15-30 \%$ of catheterassociated UTI are due to Enterococcus faecalis and Enterococcus faecium. ${ }^{90}$

\section{Nonimplant-associated biofilms}

Not all infection is due to the presence of an implant. The formation of a native biofilm is due to the presence of viable bacteria in the blood and its duration of growth (physiological bacteremia period) ${ }^{64}$ Although implant-associated biofilms have been well documented, the nonimplant-associated biofilms leading to infection are not well studied. Patients with cystic fibrosis, in which lung sections have been reported with a dense colony of Pseudomonas aeruginosa with a well-defined EPS alginate, ${ }^{91}$ is an example of a nonimplant-associated biofilm. The exact role of alginate in the biofilm architecture and in antimicrobial resistance is not well established. $^{92,93}$ Otitis media is another infection that is likely to be caused by biofilms. ${ }^{94}$ Haemophilus influenzae, Streptococcus pneumoniae and Moraxella catarrhalis are responsible for the infection of the middle ear. ${ }^{95}$

The formation of dental plaque involves five different phases as follows: (i) salivary pellicle formation, (ii) bacterial attachment, (iii) young supragingival formation, which involves colonization of Grampositive and Gram-negative cocci and rods, (iv) aged supragingival formation, which involves a higher percentage of Gram-negative anaerobes, and (v) subgingival plaque formation, which is either attached to the tooth (primarily Gram-positive and Gram-negative rods) or attached to the epithelial (primarily Gram-negative rods and spirochetes). ${ }^{43}$ Approximately 500 different bacterial strains have been isolated from dental biofilm. Periodontitis is another nonimplantassociated infection, which arises due to the presence of an oral biofilm, particularly containing Gram-negative bacteria. Porphyromonas gingivalis, a Gram-negative pathogen, together with primary tooth colonizers co-aggregate and produce protease, which interferes with the host cytokine signaling pathway. ${ }^{96}$ Salmonella enterica, Shigella sp. and Yersinia sp. are the infectious agents of arthritis. ${ }^{64}$

Colonization of uropathogens, for example, Escherichia coli, in the urinary tract causes UTI. ${ }^{97}$ Staphylococcus lugdunensis,
Enterococcus durans, Streptococci and HACEK organisms (Hemophilus parainfluenzae, Actinobacillus actinomycetemcomitans, Cardio bacterium hominis, Eikenella sp. and Kingella sp.) cause endocarditis, an inflammation of the native heart valve. ${ }^{98}$ Staphylococcus aureus is the predominant joint infection pathogen that colonizes around joints, especially the hip joints. Other Gram-positive agents that lead to joint infection include Streptococcus pyogenes, Enterococcus faecalis, and Corynebacteria sp., and Gram-negative rods that include Salmonella enterica, Shigella sp. and Yersinia sp. ${ }^{64}$ Bacterial prostitis is an ascending UTI, which is an inflammation of the prostate gland. $^{99}$ Escherichia coli, Pseudomonas aeruginosa, Klebsiella, Proteus and Bacteroides are some of the species responsible for chronic bacterial prostitis. ${ }^{70}$ These biofilms serve as a reservoir for the cells to rejuvenate and repeatedly colonize along the infected sites.

\section{ANTIBIOTIC RESISTANCE}

Most of the cells in the biofilm matrix are in the dormant state or replicate slowly, so the minimum bactericidal concentration of antimicrobial agents to eradicate the bacteria in the biofilm is higher than the amount required for free-floating ones. ${ }^{100}$ For a 1000-times reduction in the colony of Escherichia coli present in a biofilm, a three times higher dose of ampicillin is required, compared with the amount required when they are in the sessile form. ${ }^{101}$ To achieve a 1000 -times reduction in the colony of Staphylococcus aureus in a biofilm, more than 10 times the minimum bactericidal concentration of vancomycin is required. ${ }^{102}$ These bacteria are in the stationary phase or starved state, and thus only a few cells respond to the lethal effect of the antibiotic. ${ }^{24}$

Material properties have no effect on the antibiotic resistance acquired by the microbes. The antimicrobial resistance is either (i) inherent, which depends on the mode of growth of the biofilm, or (ii) acquired, which is gained by the exchange of resistant plasmids. Some of the ways by which a bacterium develops inherent bacterial resistance include the changes in the phenotype, and inactivation of antimicrobials by the extracellular polysaccharide, and the enzymes present. ${ }^{23}$ For example, the binding of EPS to tobramycin reduces the susceptibility of bacteria present in the biofilm to the drug. ${ }^{103}$ The transport of antibiotics into the biofilm matrix also decreases when bacterial cells inside the biofilm have a slow growth rate. In a Staphylococcus epidermidis biofilm, an increase in the growth rate of the strain results in increased susceptibility of the bacteria to antibiotics. ${ }^{104}$ The environment also protects the cell against antibiotics. For example, Escherichia coli entrapped within agar is less susceptible to aminoglycoside derivatives than those in free form. ${ }^{105}$ Newly formed daughter cells are more susceptible to antibiotics than the parent cells. ${ }^{106}$ Inherent resistance is multifactorial, and so multiple approaches should be adopted for the eradication of a biofilm.

Close proximity and greater probability of contact between the cells in the biofilm facilitate enhanced gene transfer. Higher cell densities in the biofilm lead to an increased local concentration of DNA. This increased concentration provides the way for horizontal gene transfer by the competence mechanism, that is, normal transformation. ${ }^{107}$ This leads to antibiotic resistance, particularly among nosocomial pathogens, ${ }^{108}$ for which DNA is the major component of the matrix. Antibiotic resistance mediated by horizontal gene transfer by a plasmid conjugal mechanism is reported in Escherichia coli. ${ }^{109}$ Conjugational plasmid transfer in the biofilm has been widely reported among the Gram-negative microorganisms. ${ }^{110}$ 


\section{FACTORS INFLUENCING BIOFILM FORMATION}

Three important factors that influence biofilm formation include (i) the nature of bacteria, (ii) the host and (iii) the surface properties of the material.

\section{Bacterial adhesins involved in biofilm formation}

Biofilm formation consists of two important stages, namely the adhesion stage, which involves firm adherence of the bacteria to the implant surface, and the maturation stage, which leads to intercellular adhesion. ${ }^{111}$

Adhesion stage. Adhesins are proteinaceous substances generally secreted by the colonizing organisms, and they are the key regulators in the adhesion stage. Adhesins bind to specific receptors on the host tissue. Adhesins are linked directly to the cell surface or to the components of the cell surface that include the pili. ${ }^{112}$ The specificity of these adhesins depends on the receptor-ligand interaction. Adhesion of Staphylococcus epidermidis to the native or the implant surface is mediated by the polysaccharide adhesins, ${ }^{113}$ and their expressions are regulated by the intracellular adhesion operon. ${ }^{114}$ Different parts of the body are affected by Streptococcal infection because they have multiple adhesins that help them to colonize everywhere. ${ }^{115}$ Attachment of Streptococcus mutans, which is primarily an oral pathogen, is also responsible for endocarditis. ${ }^{116}$ Recognition of galactose-containing moieties is necessary for the formation of an oral biofilm. ${ }^{117}$ Serine-rich repeat surface proteins are expressed on the surface of the Gram-positive pathogens. These proteins have a vital role in the adhesion process in the case of pneumococcal infection in the lungs. ${ }^{118}$ Gram-positive organisms, for example, Staphylococcus aureus, follow two different approaches: (i) at low cell densities, they produce adhesins that aid them to adhere to the implant surface, and (2) at high cell densities, they repress the regulator gene and produce more toxins to damage the tissues and enzymes, which would help them to detach from the biofilm and colonize different sites upstream. ${ }^{119}$ In addition to polysaccharide, DNA, another polymeric molecule, is found to be a part of the matrix in case of infection with Streptococcus pneumoniae, ${ }^{120}$ Pseudomonas aeruginosa $^{121}$ and Enterococcus faecalis ${ }^{122}$ biofilms, and is also responsible for holding the bacterial cells in the biofilm. The exact role of DNA in a biofilm matrix is not well established, but it is believed that, being negatively charged, it binds to the positively charged polysaccharides. ${ }^{123}$

Maturation stage. Quorum sensing (QS) is a cell-to-cell communication system and it is the key regulator that helps in the maturation of the biofilm. ${ }^{111}$ QS has an important role in communication within and between the bacterial cells. ${ }^{124}$ QSmediated response involves the production, release and detection of small molecules called pheromones or auto inducers, such as acyl homoserine lactones (AHL). The auto inducers are secreted by the bacteria when they are above a threshold concentration. The QS system includes LuxI/LuxR and its analog, which are mainly used by Gram-negative bacteria. AHL is produced by the bacterium, by the enzyme AHL synthase. At high cell densities, the concentration of AHL reaches above a threshold value, which initiates the signaling mechanism. ${ }^{125}$

Gram-positive bacteria regulate cell-to-cell signaling with the help of peptides, ${ }^{126}$ involving two-component adaptive response proteins for the detection of the auto inducers, which involves a series of phosphorylation and dephosphorylation.

Molecular mechanism. Molecular mechanism controls the assembly of the extracellular matrix, the spatio-temporal organization in the biofilm, and the cellular differentiation processes within the biofilm. ${ }^{127}$ Polysaccharide intercellular adhesin leads to pathogenicity in Staphylococcus epidermidis, ${ }^{128,129}$ whereas it does not contribute to the pathogenicity of the Staphylococcus aureus. ${ }^{130}$ In case of Staphylococcus epidermidis isolated from polymer-associated septicemic disease, a direct correlation is observed between the formation of a biofilm and an ica gene cluster. ${ }^{131}$ The gene locus, agr, in Staphylococcus aureus and Staphylococcus epidermidis, encode an amino acid toxin (hld), which aids in the detachment of the biofilm at high cell density and downregulates its formation. The agr mutants form a pronounced biofilm, clearly indicating the role of the genes. ${ }^{132,133}$ Nonfunctional agr mutants are reported from strains that cause joint prosthetic infection. ${ }^{134}$ Expression of agr is activated by another gene, sarU. ${ }^{29}$ In case of cystic fibrosis, mucoid strains overproduce alginate, which aids in the formation of a biofilm. ${ }^{135,136}$ Biofilm formation by Staphylococcus epidermidis involves two stages: the primary attachment and the maturation stage. The first step is mediated by

$\odot$ Negative Regulation

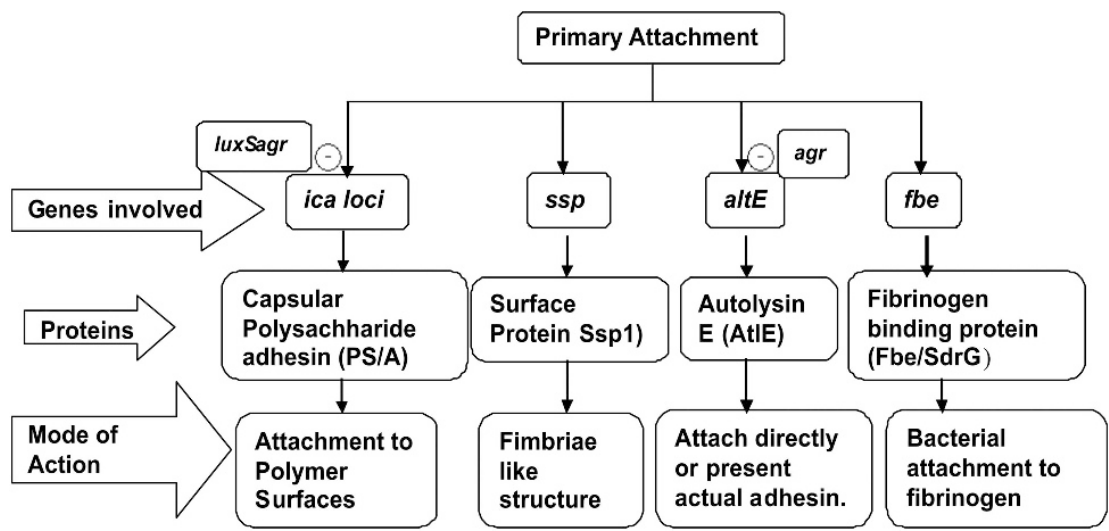

Figure 7 Molecular mechanism of the initial attachment during biofilm formation in Gram-positive Staphylococcus epidermidis. 


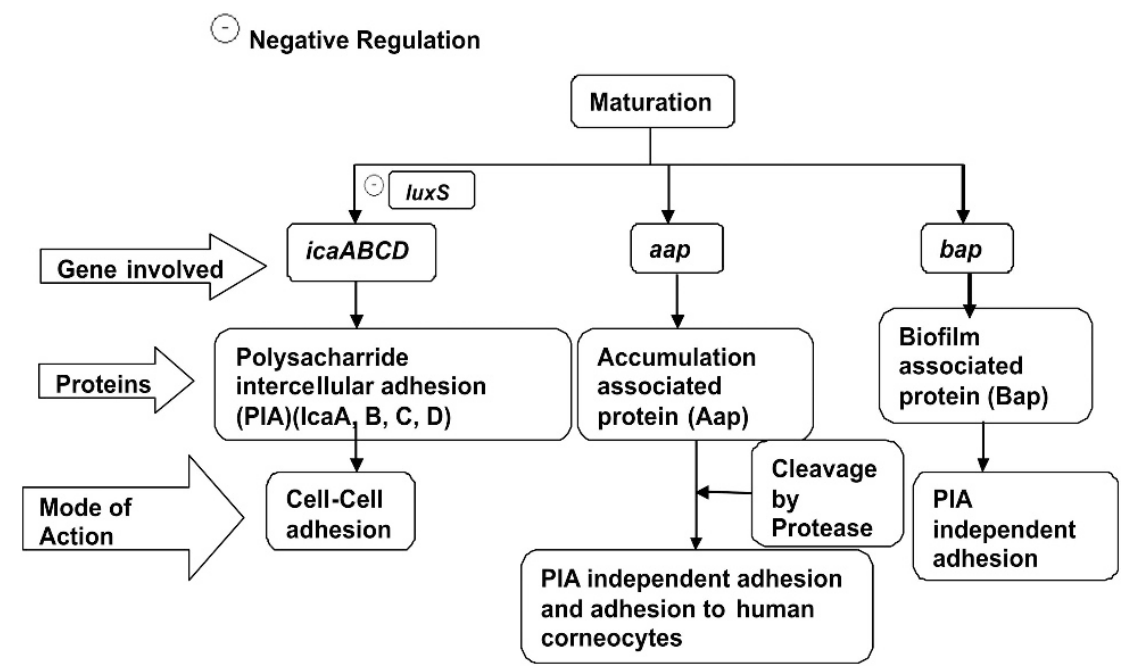

Figure 8 Molecular mechanisms during the maturation stage in Gram-positive Staphylococcus epidermidis.

the action of the genes ica loci, ssp, altE and fbe. The proteins synthesized by each of these genes differ in the mode of attachment. The ica gene loci and the altE genes are negatively regulated by the QS system. Figures 7 and 8 represent the type of genes and proteins involved and their mode of action in biofilm formation. ${ }^{137,138}$

In most of the Gram-negative bacteria, the AHL regulator genes are either expressed or suppressed based on the amount of AHL synthesized, which in turn depends on the cell densities. Binding of AHL to its receptor proteins regulates the signaling system. ${ }^{125}$ Gene $s a d B$ synthesizes a protein that is responsible for flagellar reversals and EPS secretion, and inversely regulates the biofilm formation and motility. ${ }^{139}$ In case of Salmonella typhimurium, there are genes responsible for the production of efflux pumps. With the increase in EPS production, Salmonella typhimurium develops resistance. ${ }^{140}$ Literature studies indicate that the formation and maturation of a biofilm is controlled by several molecular mechanisms; thus, a thorough understanding of the effect of cell surface regulators (adhesin), QS molecules and hydrophobicity of the surface would help in the eradication of biofilms.

\section{Role of host factors}

After they adhere to the native or the implant surface, bacterial cells immediately gain access to the host binding molecules, including fibrinogen, host extracellular matrix proteins, fibronectin and components of the blood plasma. ${ }^{141,142}$ These biomolecules act as mediators in the adhesion of the bacterium. As mentioned earlier, serum proteins compete with bacterial cells to attach onto the material surface. They also provide a number of specific and nonspecific sites for the binding of bacterial adhesins, ${ }^{16}$ which increases the cell density within $24 \mathrm{~h}$. The amount of bacterial cells during the various stages in the biofilm formation regulates the expression of host innate immunity genes, particularly the antimicrobial peptides, human $\beta$-defensin-2, psoriasin, ribonuclease- 7 and inflammatory mediators. ${ }^{143}$

The immunocompromised state generally contributes to biofilm formation and infection. This state ranges from leukopenia (decrease in the number of white blood cells) to malnutrition in the patient. ${ }^{144,145}$ Joint replacement, diabetes and psoriasis also increase the risk of infection. The maintenance of a constant physiological state (homeostasis) at the implant site has an important role in providing a proper defense mechanism against infection. Optimum blood flow in tissues, oxygen tension and cellular arrangement enhances the host defense mechanism. Tissue coverage over the hip and knee implant surface is necessary to prevent bacterial adhesion. Predisposing factors in the case of ureteral stent infection include the in-dwelling time, the patient's sex and the presence of other systemic diseases, including diabetes mellitus, chronic renal failure and diabetic nephropathy. ${ }^{146}$

\section{Substrate characteristics}

Hydrophobicity, roughness, surface chemistry and surface free energy of the implants have an important role in the attachment of bacteria and in biofilm formation. In majority of cases, hydrophobic and rough surfaces favor biofilm formation. ${ }^{147}$ An increase in the surface energy also enhances bacterial adherence to the implant surface. ${ }^{148,149}$ An increase in the surface roughness above a certain threshold (approximately $0.2 \mu$ ) facilitates biofilm formation. ${ }^{150,151}$ Polishing can decrease surface roughness, and hence decrease the attachment of bacteria. However, polishing can also alter the physico-chemical properties of the implant. Attempts to polish composite resin used in dental implants make it more inorganic and rough, and increase bacterial adhesion. ${ }^{152}$ On the other hand, bacterial adhesion is greatly reduced on a polished stainless steel microtopography. ${ }^{153}$ A microcavity is another important factor that affects bacterial adhesion. In vitro results have reported that bacterial cells exhibit reduced adhesion to titanium and resorbable polylactide plates, which is attributed to the surface charge and smoothness. ${ }^{154}$ This reduced adhesion is also consistent with the reduced incidence of infection in case of patients who received implants made of these materials.

Bacterial adherence to the surface of the implants is mediated by hydrophobic and electrostatic interactions. ${ }^{155}$ Hydrophobic organisms adhere well onto hydrophobic surfaces, ${ }^{156}$ and hydrophilic Escherichia coli binds well onto hydrophilic catheters. ${ }^{157}$ Pseudomonas aeruginosa adheres well onto hydrophilic, electrically neutral and smooth polymeric surfaces. ${ }^{158}$ This indicates that surface hydrophobicity alone does not determine the bacterial adhesion. Electrostatic interactions have an important role in determining the attraction or repulsion of bacterial surface to the implant. This varies with respect 
to the type of strain and the material involved. ${ }^{159}$ Medical implants that are primarily embedded in a fluid environment gains an additional layer of organic matrix, a conditioning layer, which completely masks its properties. ${ }^{20}$ Although differences in the thickness of biofilm formation and amount of bacterial attachment could be attributed to the surface properties of the implant, it is clear that these properties have no effect on the antibacterial resistance acquired by the biofilm. Nevertheless, researchers have observed that antibacterial resistance is also related to the material properties because of the degree of colonization of the bacteria. This, in turn, depends on the surface chemistry and properties of the implant. ${ }^{66,160,161}$

In case of metallic implants, surface charge has an important role in the adhesion of bacteria. An optimum surface charge enhances the adherence of soft tissue, thereby reducing infection at the implant site. ${ }^{162}$ An in vitro postoperative contamination study has observed that critical cell coverage is an important factor to prevent bacterial adhesion. ${ }^{163}$ Enhanced cell adhesion, in turn, depends on the surface characteristics of the implant. The chemical composition and the design of the implant also have an important role in bacterial adhesion. ${ }^{148}$ Increased bacterial adhesion on anionic surfaces in the first $24 \mathrm{~h}$ compared with that on cationic surface has been observed. At later time, intercellular adhesion has a more important role than the surface effects. ${ }^{16}$ A positively charged surface exerts an antibacterial effect on the Gram-negative strains, whereas the initial attachment of bacteria is slow on negatively charged surfaces, but the rate of growth of bacteria later is high on this surface. ${ }^{164}$

\section{DIAGNOSTIC METHODS FOR THE IDENTIFICATION OF BIOFILMS}

Culture detection

Most bacteria in the biofilm matrix escape the standard microbiological culture techniques. The aseptic loosening of joint prosthesis could be attributed to bacteria that are not detected by the conventional microbiological techniques. ${ }^{165}$ The ultrasonication method aids in the detection and enhances the identification of these bacteria. ${ }^{165}$ Tools such as $16 \mathrm{~S}$ ribosomal RNA detection with PCR, ${ }^{166}$ or reverse-transcriptase $\mathrm{PCR}^{167}$ and histopathological analysis of the tissues provide the most accurate approach for the detection of the microorganism.

Vortexing and water bath sonication of the retrieved implants to dislodge bacterial cells from the biofilm matrix, followed by culturing, is used to detect the bacteria. This is more sensitive than the conventional peri-implant tissue culture analysis. ${ }^{168}$ Sonication is a valuable method in the detection of ureteral stent colonization. Estimation of C-reactive protein provides a screening test to diagnose infection in the case of postoperative hip and knee implants, ${ }^{169}$ and in cardiac surgery. ${ }^{170}$ Measurement of interleukin6 can be used in deep implant infections. ${ }^{171}$ Procalcitonin and TNF $\alpha$ are also very specific in detecting infection, but have very low sensitivity.

\section{Imaging studies}

In addition to the conventional microbiological analysis, plain X-ray and ultrasound sonography is also used to study biofilm. These methods are not sensitive or accurate in detecting the type of microorganism, but they give a clear picture of the morphology of the biofilm and hence help to understand the extent of infection. ${ }^{5}$ For example, aseptic loosening, which is generally attributed to nondetectable bacterial colonization, could be analyzed using these techniques. Nuclear imaging analysis with ${ }^{99 \mathrm{~m}} \mathrm{Tc}$ (Technetium-99m)- labeled monoclonal antibodies ${ }^{5}$ is an accurate method for the detection of infection. For example, ${ }^{99} \mathrm{~m} \mathrm{Tc}-\mathrm{WBC}$ is widely used in the diagnosis of vascular graft infection. Computed tomography and magnetic resonance imaging provide additional information about the anatomical features in case of infected implants, but the disadvantage of these techniques are interferences caused by the metals used in the implants, which restricts their applications to soft tissue abnormalities. ${ }^{5}$ Positron emission tomography-computed tomography is used in the detection of implant-based osteomyelitis. ${ }^{172}$ An echocardiogram is used to diagnose endocarditis in the case of prosthetic valve infection. The combination of these imaging studies helps in minimizing false diagnosis and provides a composite picture.

\section{CURRENT TREATMENT STRATEGIES}

Several physical, chemical and biological methods are practiced to modify the implant surface to improve its biocompatibility and reduce bacterial adhesion. Different approaches are practiced for different materials, including polymers, metals and ceramics, which is schematically represented in Figure 9. The modification is intended to alter only the surface without affecting the bulk properties of the material. There is no single strategy that can be used for any material and for all situations. The modification strategy also depends on the duration the implant is in the body. Despite a number of therapeutic approaches, there is no single successful treatment strategy for infected dental implants. Current strategies include mechanical removal of the infected part, creating anaerobic conditions by correct anatomical positions, using systemic and local antibiotics, ${ }^{173}$ and surgical interventions. ${ }^{174}$ Delaying surgical interventions after tooth extraction with random pre- and postoperative antibiotic treatment reduces biofilm formation. ${ }^{175}$ In contrast, in orthopedic implants, resection arthroplasty, which involves definitive removal of infected tissues and implants parts, followed by antibiotic treatment for 4-6 weeks, is practiced successfully. ${ }^{62}$ The success rate in the eradication of infection is $60-100 \%$ in case of total hip arthroplasty, whereas it is $89 \%$ in case of total knee arthroplasty. ${ }^{176}$

The use of antimicrobial impregnated cement for local drug delivery, ${ }^{177,178}$ initial debridement of infected tissues followed by antibiotic treatment, polishing the implant surface to reduce surface roughness, and the use of antibiotic impregnated devices are some of the strategies currently employed for knee ${ }^{179}$ and hip implants. ${ }^{180}$ In case of stable implants, an antimicrobial treatment regime is used for short-term infection. ${ }^{181}$ Maintaining an adequate concentration of prophylactic antibiotics in the perigraft tissues throughout the duration of the procedure prevents vascular graft infection. ${ }^{182}$ The use of a muscle flap greatly reduces the risk associated with graft infection. ${ }^{183}$ In case of a urological implant, because the sensitive urine culture is low, Ciprofloxacin is used as prophylaxis before stent insertion, whereas amino glycosides are administered in case of symptomatic patients. ${ }^{184}$

\section{FUTURE TRENDS TO ADDRESS FACTORS INFLUENCING MEDICAL BIOFILMS}

The development of biofilms is not thoroughly understood; hence, designing surfaces to prevent bacterial attachment is a challenging area of research. There are several methods by which this problem could be approached.

\section{Targeting bacteria}

The correlation between biofilm formation and bacterial persistence is well established; ${ }^{162}$ more potent drugs that target biofilm formation 


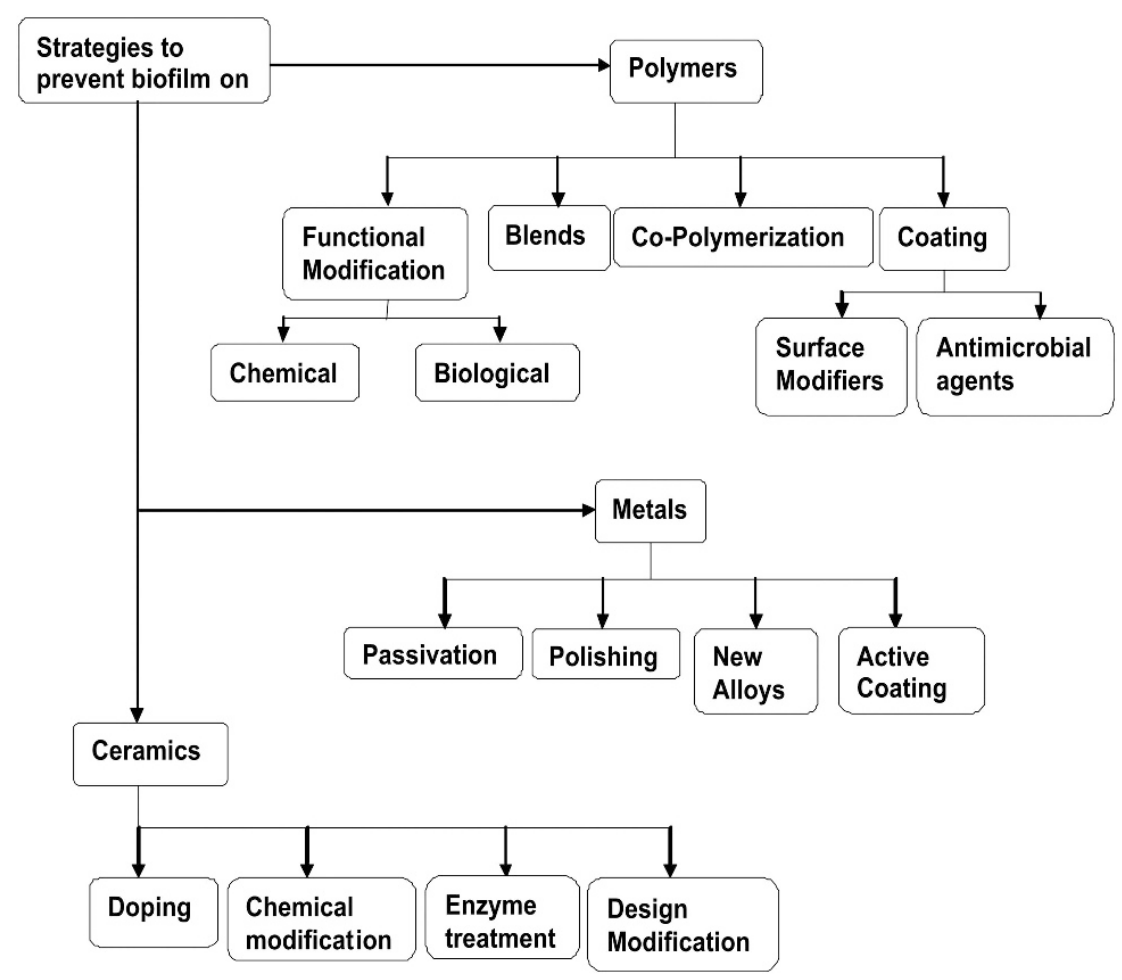

Figure 9 Strategies to prevent biofilm formation on implants.

and act against sessile bacteria need to be designed. ${ }^{185}$ Bacterial biofilm formation can be addressed at three levels: (i) preventing receptor binding, (ii) inhibiting bacterial adhesion and (iii) targeting the QS signaling molecules.

Exposing the planktonic cells to a biofilm-preventing stress factor reduces the risk of their attachment to surfaces. Nonsteroidal antiinflammatory drugs, molecules secreted by bacteria and QS inhibitor molecules are some of the stress factors widely used to prevent biofilm formation. ${ }^{186}$ Most of the biofilm inhibitor molecules target either the auto inducer molecule that aid in QS or directly the QS molecule. The QS inhibitor molecules include polypeptides that inhibit the RNAIII activator protein of the QSQ1 in Gram-positive bacterium, ${ }^{187}$ furanones that are active against swarming Proteus mirabilis and Serratia, ${ }^{188-190}$ and AHL analogs with various substitutions that repress the QS activity. ${ }^{191,192}$ Most natural compounds, including furanones, are found to be active against environmental biofilm, ${ }^{193}$ but there is no clinical evidence for the successful application of these in humans. Adhesins stabilize the biofilm both in the growth phase and in the maturation phase. Immunizing the individual against bacterial adhesins would prevent biofilm formation and even bacterial adhesion, ${ }^{194}$ for example, preclinical studies with vaccines with FimH adhesin and other conserved adhesin from a uropathogenic Escherichia coli have proven that the immune response against the adhesin can prevent bacterial adhesion and colonization. ${ }^{195,196}$ Pharmaceutical companies spend billions of dollars on discovery of new drugs, but less attention is directed towards designing new compounds that would prevent biofilm formation on surfaces. The current trend has been to test the efficacy of existing drugs as possible candidates for biofilm prevention rather than discover specific ones that are based on the molecular level interaction between the bacteria and the abiotic surface.

\section{Material design}

Engineering the surface roughness ${ }^{197}$ to obtain the desired topographical features that inhibit biofilm formation is another approach. A passive polymer coating reduces bacterial adhesion to the implant surface by altering the surface chemistry of the implant. ${ }^{198}$ Coating the surface with antimicrobial agents could lead to resistant strains. Non-antimicrobial modification of the implant surface includes the use of nonsteroidal anti-inflammatory agents, hydroxyapatite, hydrophilic polymer, gelatin and surfactants. There is no well-documented clinical evidence for the benefits of this type of modification to the implant surface. Active polymer coatings with antimicrobials greatly reduce bacterial adhesion. Nitric oxide modifies the bacterial cell membrane and disperses biofilm formation. ${ }^{199}$ Materials that release nitric oxide, unlike conventional antibiotics, have also been successful. Biodegradable antimicrobialcoated implants with a controlled release that provide high local concentration without systemic toxic effects helps to reduce infection at the implant site. ${ }^{200}$

The coating of a nonpathogenic strain on polymeric implants helps to prevent the formation of biofilm by other bacteria, provided the potential risk in introducing these strains is addressed. For example, coating of polymer with Lactobacillus acidophilus decreases the adherence of Staphylococcus epidermidis and E. coli. ${ }^{201}$ Similarly, in case of patients with spinal cord injury, inoculating their bladder with nonpathogenic E.coli protects them against the symptomatic UTI. ${ }^{202}$ Binding specific antimicrobial peptides to metallic surfaces, ${ }^{203}$ and antibody-coated and biomimmetic stents are novel ideas in the field of biocovered polymers. For example, biomimmetic polymers coated with poly (2-methacryloyloxyethyl phosphorylcholine) resists the adsorption of plasma protein, irrespective of its charge and size [A]. Such an approach is adopted to improve the biocompatibility and 
hemocompatibility of different medical materials $[B][C]$. This poly (2-methacryloyloxyethyl phosphorylcholine), when conjugated with protein, increases the half life of the latter in the blood [D]. Hydrogels are inert polymeric networks that are suitable as carriers of antimicrobial agents. ${ }^{204,205}$ Iron-oxide nanoparticles are used to depolymerize EPS, inactivate enzymes and damage DNA. ${ }^{206}$

\section{Computational approach}

The growth of biofilms based on the nutrient supply can be mathematically modeled. Confocal laser scanning microscope and RNA target probes can provide information about the morphology, architecture and function of the biofilm, which can be used for validating such models. The earlier one-dimensional model ${ }^{207,208}$ is improved with three-dimensional models of biofilms. The biofilm is considered as a biological gel consisting of EPS and water. ${ }^{209}$ Interspecies antagonistic effects that are mediated by certain molecules is also modeled. For example, siderophore-mediated antagonism in dual-species biofilms, which chelates iron, is established through modeling. ${ }^{210}$ The effect of EPS on biofilm structure and function is also simulated using one ammonia and nitrite oxidizing species. EPS production is found to decrease the growth of producers and stimulate the growth of nonproducers. ${ }^{211}$

Simulation studies to analyze the effect of probiotic biofilms on pathogenic biofilms indicate that the attachment of probiotics in the flow channel is crucial for success and efficacy of the probiotic control mechanism. ${ }^{212}$ The viscoelastic fluid property of biofilms is modeled in response to the mechanical forces. ${ }^{213}$ Such a study can provide insight into the effect of external forces on the stability of biofilm.

\section{CONCLUSION}

Implant-associated bacterial infection has a pernicious role in medicine. Despite various findings on the physical and biochemical parameter of the bacteria and the surface characteristics of the implant, the need for an ideal material still exists. Use of computational and modeling tools to simulate the interaction of bacterial proteins and other biomolecules with synthetic and abiotic surfaces can provide insight for understanding the early stages in the formation of biofilm. These techniques can also elucidate some of the lacunae observed in the in vitro and in vivo studies. Once these simulation tools are well established, with combined genetic and biochemical techniques one could identify the molecular regulatory circuits that govern the transition from motile cells to matrixenclosed, implant-surface-associated bacteria. This identification would help in designing biomaterials that function correctly in the first instance when tested in the laboratory, thereby accelerating the product development phase. Such simulation tools may also help in suggesting the best surface modification strategy for a given environment.

\section{CONFLICT OF INTEREST}

The authors declare no conflict of interest.

\section{ACKNOWLEDGEMENTS}

We thank Dr Sunil Shroff, Professor and Head, Department of Urology, Sri Ramachandra University, Chennai, for the ureteral stent photograph; Mrs Vinodhini Sridharan, Assistant Professor, Department of Pharmacology, SRM Dental College, Chennai, for the dental implant photograph; and Dr Ravichand Ismavel, Assistant Professor, Department of Orthopedics, $\mathrm{CMC}$, Vellore, for the orthopedic implant photograph.
1 Jass, J., Surman, S. \& Walker, J. T. Medical Biofilms: Detection, Prevention, and Control Vol. 2 (Wiley, UK, 2003).

2 Richards, M. J., Edwards, J. R., Culver, D. H. \& Gaynes, R. P. Nosocomial infections in medical intensive care units in the United States. Crit. Care Med. 27, 887 (1999).

3 O'Toole, G., Kaplan, H. B. \& Kolter, R. Biofilm formation as microbial development. Annu. Rev. Microbiol. 54, 49-79 (2000).

4 Zhang, X., Bishop, P. L. \& Kupferle, M. J. Measurement of polysaccharides and proteins in biofilm extracellular polymers. Water Sci. Technol. 37, 345-348 (1998).

5 Trampuz, A. \& Zimmerli, W. Diagnosis and treatment of infections associated with fracture-fixation devices. Injury 37, S59-S66 (2006).

6 Gustilo, R. B., Gruninger, R. P. \& Davis, T. Classification of type III (severe) open fractures relative to treatment and results. Orthopedics 10, 1781 (1987)

7 Willenegger, H. \& Roth, B. [Treatment tactics and late results in early infection following osteosynthesis]. Unfallchirurgie 12, 241 (1986).

8 Arens, S., Hansis, M., Schlegel, U., Eijer, H., Printzen, G., Ziegler, W. J. \& Perren, S. $M$. Infection after open reduction and internal fixation with dynamic compression plates-clinical and experimental data. Injury 27(Suppl 3), SC27-SC33 (1996).

9 Arens, S., Kraft, C., Schlegel, U., Printzen, G., Perren, S. M. \& Hansis, M. Susceptibility to local infection in biological internal fixation. Experimental study of open vs minimally invasive plate osteosynthesis in rabbits. Arch. Orthop. Trauma Surg. 119, 82-85 (1999).

10 Law, Jr M. D. \& Stein, R. E. Late infection in healed fractures after open reduction and internal fixation. Orthopaed. Rev. 22, 545 (1993).

11 Maderazo, E. G., Judson, S. \& Pasternak, H. Late infections of total joint prostheses: a review and recommendations for prevention. Clin. Orthop. Relat. Res. 229, 131 (1988)

12 Campoccia, D., Montanaro, L. \& Arciola, C. R. Current methods for molecular epidemiology studies of implant infections. Int. J. Artif. Organs 32, 642 (2009)

13 Baldassarri, L., Donnelli, G., Gelosia, A., Voglino, M. C., Simpson, A. W. \& Christensen, G. D. Purification and characterization of the staphylococcal slimeassociated antigen and its occurrence among Staphylococcus epidermis clinical isolates. Infect. Immun. 64, 3410-3415 (1996).

14 Hussain, M., Wilcox, M. H. \& White, P. J. The slime of coagulase-negative staphylococci: biochemistry and relation to adherence. FEMS Microbiol. Lett. 104, 191-207 (1993).

15 Hazan, Z., Zumeris, J., Jacob, H., Raskin, H., Kratysh, G., Vishnia, M., Dror, N., Barliya, T., Mandel, M. \& Lavie, G. Effective prevention of microbial biofilm formation on medical devices by Low-Energy Surface Acoustic Waves. Antimicrob. Agents Chemother. 5, 4144-4152 (2006).

16 MacKintosh, E. E., Patel, J. D., Marchant, R. E. \& Anderson, J. M. Effects of biomaterial surface chemistry on the adhesion and biofilm formation of Staphylococcus epidermidis in vitro. J. Biomed. Mater. Res. A 78, 836-842 (2006).

17 Korber, D. R., Lawrence, J. R., Sutton, B. \& Caldwell, D. E. Effect of laminar flow velocity on the kinetics of surface recolonization by Mot + and Mot - Pseudomonas fluorescens. Microb. Ecol. 18, 1-19 (1989).

18 Rosenberg, M., Bayer, E. A., Delarea, J. \& Rosenberg, E. Role of thin fimbriae in adherence and growth of Acinetobacter calcoaceticus RAG-1 on hexadecane. Appl. Environ. Microbiol. 44, 929 (1982).

19 Donlan, R. M. Biofilms and device-associated infections. Emerg. Infect. Dis. 7, 277 (2001).

20 Donlan, R. M. Biofilm formation: a clinically relevant microbiological process. Clin. Infect. Dis. 33, 1387 (2001).

21 Picioreanu, C., van Loosdrecht, M. C. M. \& Heijnen, J. J. Two-dimensional model of biofilm detachment caused by internal stress from liquid flow. Biotechnol. Bioeng. 72, 205-218 (2001).

22 Stoodley, P., Cargo, R., Rupp, C. J., Wilson, S. \& Klapper, I. Biofilm material properties as related to shear-induced deformation and detachment phenomena. J. Ind. Microbiol. Biotechnol. 29, 361-367 (2002).

23 Gilbert, P., Das, J. \& Foley, I. Biofilms susceptibility to antimicrobials. Adv. Dent. Res. 11, 160-167 (1997)

24 Costerton, J., Stewart, P. \& Greenberg, E. Bacterial biofilms: a common cause of persistent infections. Science 284, 1318-1322 (1999).

25 Daly, B., Betts, W. B., Brown, A. P. \& O'Neill, J. G. Bacterial loss from biofilms exposed to free chlorine. Microbios 96, 7-21 (1998).

26 Lee, S. F., Li, Y. H. \& Bowden, G. H. Detachment of Streptococcus mutans biofilm cells by an endogenous enzymatic activity. Infect. Immun. 64, 1035 (1996).

27 Ji, Y. K. \& Ling, J. Q. [Spatial distribution of dead and vital bacteria in the native dental biofilm]. Zhonghua Kou Qiang Yi Xue Za Zhi 42, 294 (2007).

28 Lewis, K. Persister cells and the riddle of biofilm survival. Biochemistry (Moscow) 70, 267-274 (2005).

29 Yarwood, J. M., Paquette, K. M., Tikh, I. B., Volper, E. M. \& Greenberg, E. P. Generation of virulence factor variants in Staphylococcus aureus biofilms. J. Bacteriol. 189, 7961 (2007).

30 Boles, B. R., Thoendel, M. \& Singh, P. K. Self-generated diversity produces 'insurance effects' in biofilm communities. Proc. Natl Acad. Sci. USA 101, 16630 (2004).

31 Allegrucci, M. \& Sauer, K. Characterization of colony morphology variants isolated from Streptococcus pneumoniae biofilms. J. Bacteriol. 189, 2030 (2007).

32 Handke, L. D., Conlon, K. M., Slater, S. R., Elbaruni, S., Fitzpatrick, F., Humphreys, H., Giles, W. P., Rupp, M. E., Fey, P. D. \& O'Gara, J. P. Genetic and phenotypic analysis of biofilm phenotypic variation in multiple Staphylococcus epidermidis isolates. J. Med. Microbiol. 53, 367-374 (2004). 
33 Hansen, S. K., Haagensen, J. A. J., Gjermansen, M., Jorgensen, T. M., Tolker-Nielsen T. \& Molin, S. Characterization of a Pseudomonas putida rough variant evolved in a mixed-species biofilm with Acinetobacter sp. strain C6. J. Bacteriol. 189, 4932-4943 (2007)

34 Vance, R. E., Zhu, J. \& Mekalanos, J. J. A constitutively active variant of the quorumsensing regulator LuxO affects protease production and biofilm formation in Vibrio cholerae. Infect. Immun. 71, 2571 (2003).

35 Grau, B. L., Henk, M. C. \& Pettis, G. S. High-frequency phase variation of Vibrio vulnificus 1003: isolation and characterization of a rugose phenotypic variant. J. Bacteriol. 187, 2519 (2005)

36 Ingavale, S., Van Wamel, W., Luong, T. T., Lee, C. Y. \& Cheung, A. L. Rat/MgrA, a regulator of autolysis, is a regulator of virulence genes in Staphylococcus aureus. Infect. Immun. 73, 1423 (2005).

37 Seidl, K., Muller, S., Francois, P., Kriebitzsch, C., Schrenzel, J., Engelmann, S., Bischoff, M. \& Berger-Bachi, B. Effect of a glucose impulse on the CcpA regulon in Staphylococcus aureus. BMC Microbiol. 9, 95-111 (2009).

38 Vuong, C. \& Otto, M. Staphylococcus epidermidis infections. Microbes Infect. 4 481-489 (2002).

39 Wang, L., Li, M., Dong, D., Bach, T. H., Sturdevant, D. E., Vuong, C., Otto, M. \& Gao, Q. SarZ is a key regulator of biofilm formation and virulence in Staphylococcus epidermidis. J. Infect. Dis. 197, 1254-1262 (2008).

40 Rijavec, M., Müller-Premru, M., Zakotnik, B. \& Žgur-Bertok, D. Virulence factors and biofilm production among Escherichia coli strains causing bacteraemia of urinary tract origin. J. Med. Microbiol. 57, 1329 (2008).

41 Parkins, M. D., Ceri, H. \& Storey, D. G. Pseudomonas aeruginosa GacA, a factor in multihost virulence, is also essential for biofilm formation. Mol. Microbiol. 40, 1215-1226 (2001).

$42 \mathrm{Koo}$, H., Xiao, J. \& Klein, M. I. Extracellular polysaccharides matrix-an often forgotten virulence factor in oral biofilm research. Int. J. Oral Sci. 1, 229-234 (2009).

43 Nield-Gehrig, J. S. Dental plaque biofilms. J. Pract. Hygiene 14, 16 (2005).

44 Pye, A. D., Lockhart, D. E. A., Dawson, M. P., Murray, C. A. \& Smith, A. J. A review of dental implants and infection. J. Hosp. Infect. 72, 104-110 (2009).

45 Adell, R., Lekholm, U., Rockler, B. \& Brånemark, P. A 15-year study of osseointegrated previous term implants next term in the treatment of the edentulous jaw. Int. J. Oral Surg. 10, 387-416 (1981).

46 Renvert, S., Samuelsson, E., Lindahl, C. \& Persson, G. Mechanical non surgical treatment of peri implantitis: a double blind randomized longitudinal clinical study. I: clinical results. J. Clin. Periodont. 36, 604-609 (2009).

47 Balaji, S. M. Textbook of Oral And Maxillofacial Surgery. 1 edn (Elsevier, India, 2007).

48 Saxton, C. Scanning electron microscopy study of the formation of dental plaque. Caries Res 19, 111-123 (1973).

49 Maximo, M. B., de Mendonca, A. C., Renata Santos, V., Figueiredo, L. C., Feres, M. \& Duarte, P. M. Short term clinical and microbiological evaluations of peri implant diseases before and after mechanical anti infective therapies. Clin. Oral Implan. Res. 20, 99-108 (2009)

50 Rams, T. E. \& Link, Jr C. C. Microbiology of failing dental implants in humans: electron microscopic observations. J. Oral Implantol. 11, 93 (1983).

51 Heimdahl, A., Köndell, P. A., Nord, C. E. \& Nordenram, A. Effect of insertion of osseointegrated prosthesis on the oral microflora. Swed. Dent. J. 7, 199 (1983).

52 Krekeler, G., Pelz, K. \& Nelissen, R. Mikrobielle Besiedlung der Zahnfleischtaschen am künstlichen Titanpfeiler. Dtsch. Zahnarztl. Z 41, 569-572 (1986).

53 Mombelli, A., Oosten, M. A. C., Schürch, Jr E. \& Lang, N. P. The microbiota associated with successful or failing osseointegrated titanium implants. Oral Microbiol. Immun. 2, 145-151 (1987).

54 Sanz, M., Newman, M. G., Nachnani, S., Holt, R., Stewart, R. \& Flemmig, T. Characterization of the subgingival microbial flora around endosteal sapphire dental implants in partially edentulous patients. Int. J. Oral. Maxillofac. Implants 5, 247-253 (1990)

55 Becker, W., Becker, B. E., Newman, M. G. \& Nyman, S. Clinical and microbiologic findings that may contribute to dental implant failure. Int J Oral Maxillofac Implants 5, 31 (1990)

56 Rams, T. E., Feik, D. \& Slots, J. Staphylococci in human periodontal diseases. Oral Microbiol. Immun. 5, 29-32 (1990).

57 Augthun, M. \& Conrads, G. Microbial findings of deep peri-implant bone defects. Int J. Oral Maxillofac. Implants 12, 106 (1997)

58 Leonhardt, Å., Dahlén, G. \& Renvert, S. Five-year clinical, microbiological, and radiological outcome following treatment of peri-implantitis in man. J. Periodont. 74, 1415-1422 (2003).

59 Mombelli, A. \& Décaillet, F. The characteristics of biofilms in peri implant disease. J. Clin. Periodont. 38, 203-213 (2011).

60 Saginur, R., StDenis, M., Ferris, W., Aaron, S. D., Chan, F., Lee, C. \& Ramotar, K. Multiple combination bactericidal testing of staphylococcal biofilms from implantassociated infections. Antimicrob. Agents Chemother. 50, 55-61 (2006).

61 Lauderdale, K. J., Malone, C. L., Boles, B. R., Morcuende, J. \& Horswill, A. R. Biofilm dispersal of community associated methicillin resistant Staphylococcus aureus on orthopedic implant material. J. Orthopaed. Res. 28, 55-61 (2010).

62 Sia, I. G., Berbari, E. F. \& Karchmer, A. W. Prosthetic joint infections. Infect. Dis. Clin. North Am. 19, 885-914 (2005).

63 Bengtson, S., Blomgren, G., Knutson, K., Wigren, A. \& Lidgren, L. Hematogenous infection after knee arthroplasty. Acta. Orthop. Scand. 58, 529-534 (1987).

64 Geipel, U. Pathogenic organisms in hip joint infections. Int. J. Med. Sci. 6, 234 (2009).
65 Cuckler, J. M. The infected total knee: management options. J. Arthroplasty 20 33-36 (2005).

66 Gristina, A. G., Jennings, R. A., Naylor, P. T., Myrvik, Q. N. \& Webb, L. X. Comparative in vitro antibiotic resistance of surface-colonizing coagulase-negative staphylococci. Antimicrob. Agents Chemother. 33, 813 (1989).

$67 \mathrm{Ha}, \mathrm{K}$. Y., Chung, Y. G. \& Ryoo, S. J. Adherence and biofilm formation of Staphylococcus epidermidis and Mycobacterium tuberculosis on various spinal implants. Spine 30, 38 (2005)

68 Lynch, A. S. \& Robertson, G. T. Bacterial and fungal biofilm infections. Annu. Rev. Med. 59, 415-428 (2008).

69 Donlan, R. M. \& Costerton, J. W. Biofilms: survival mechanisms of clinically relevant microorganisms. Clin. Microbiol. Rev. 15, 167 (2002).

70 Kokare, C. R., Chakraborty, S., Khopade, A. N. \& Mahadik, K. R. Biofilm: Importance and applications. Indian J. Biotechnol. 8, 159-168 (2009).

71 Litzler, P. Y., Benard, L., Barbier-Frebourg, N., Vilain, S., Jouenne, T., Beucher, E., Bunel, C., Lemeland, J. F. \& Bessou, J. P. Biofilm formation on pyrolytic carbon heart valves: influence of surface free energy, roughness, and bacterial species. J. Thorac. Cardiovas. Surg. 134, 1025-1032 (2007).

72 Calderwood, S. B., Swinski, L. A., Waternaux, C. M., Karchmer, A. W. \& Buckley, M. J. Risk factors for the development of prosthetic valve endocarditis. Circulation 72, 31 (1985).

73 Grover, F. L., Cohen, D. J., Oprian, C., Henderson, W. G., Sethi, G. \& Hammermeister, K. E. Determinants of the occurrence of and survival from prosthetic valve endocarditis: experience of the Veterans Affairs Cooperative Study on Valvular Heart Disease. J. Thorac. Cardiovas. Surg. 108, 207-214 (1994).

74 Baumgartner, W. A., Miller, D. C., Reitz, B. A., Oyer, P. E., Jamieson, S. W., Stinson, E. B. \& Shumway, N. E. Surgical treatment of prosthetic valve endocarditis. Ann. Thorac. Surg. 35, 87-104 (1983).

75 Vongpatanasin, W., Hillis, L. D. \& Lange, R. A. Prosthetic heart valves. N. Engl. J. Med. 335, 407-416 (1996).

76 Schmitt, D. D., Bandyk, D. F., Pequet, A. J. \& Towne, J. B. Bacterial adherence to vascular prostheses. A determinant of graft infectivity. J. Vasc. Surg. 3, 732 (1986).

77 Bunt, T. J. Synthetic vascular graft infections. I. Graft infections. Surgery 93, 733 (1983).

78 Seeger, J. M. Management of patients with prosthetic vascular graft infection Am.Surg. 66, 166-177 (2000)

79 Zetrenne, E., McIntosh, B. C., McRae, M. H., Gusberg, R., Evans, G. R. D. \& Narayan, D. Prosthetic vascular graft infection: a multi-center review of surgical management. Yale J. Biol. Med. 80, 113-121 (2007).

80 Narasimhan, S., Aslam, S., Lin, P. H., Bechara, C. F., Mansouri, M. D. \& Darouiche, R. O. Bacterial translocation across ePTFE vascular graft surfaces. J. Infect. 60 486-490 (2010).

81 Venkatesan, N., Shroff, S., Jayachandran, K. \& Doble, M. Polymers as ureteral stents. J. Endourol. 24, 191-198 (2010).

82 Reid, G., Denstedt, J. D., Kang, Y. S., Lam, D. \& Nause, C. Microbial adhesion and biofilm formation on ureteral stents in vitro and in vivo. J. Urol. 148, 1592 (1992)

83 Riedl, C. R., Plas, E., Hubner, W. A., Zimmerl, H., Ulrich, W. \& Pfluger, H. Bacteria colonization of ureteral stents. Eur. Urol. 36, 53-59 (2000).

84 Licht, M. R., Montague, D. K., Angermeier, K. W. \& Lakin, M. M. Cultures from genitourinary prostheses at reoperation: questioning the role of Staphylococcus epidermidis in periprosthetic infection. J. Urol. 154, 387-390 (1995).

85 Costerton, J. W., Lewandowski, Z., Caldwell, D. E., Korber, D. R. \& Lappin-Scott, H. M. Microbial biofilms. Annu. Rev. Microbiol. 49, 711-745 (1995).

86 Evans, B., Silverstein, A. D. \& Donatucci, C. F. Biofilm formation on clinically noninfected penile prosthetic surfaces. Int. J. Impot. Res. 15, S162 (2003).

87 Garibaldi, R. A., Burke, J. P., Britt, M. R., Miller, W. A. \& Smith, C. B. Meata colonization and catheter-associated bacteriuria. N. Engl. J. Med. 303, 316-318 (1980).

88 Norden, C. W., Green, G. M. \& Kass, E. H. Antibacterial mechanisms of the urinary bladder. J. Clin. Invest. 47, 2689 (1968).

89 Kucheria, R., Dasgupta, P., Sacks, S., Khan, M. \& Sheerin, N. Urinary tract infections: new insights into a common problem. Postgrad. Med. J. 81, 83 (2005).

90 Maki, D. G. \& Tambyah, P. A. Engineering out the risk for infection with urinary catheters. Emerg. Infect. Dis. 7, 342 (2001)

91 Collins, F. S. Cystic fibrosis: molecular biology and therapeutic implications. Science 256, 774-779 (1992).

92 Boyd, A. \& Chakrabarty, A. M. Pseudomonas aeruginosa biofilms: role of the alginate exopolysaccharide. J. Ind. Microbiol. 15, 162-168 (1995)

93 Cochran, W. L., Suh, S. J., McFeters, G. A. \& Stewart, P. S. Role of RpoS and AlgT in Pseudomonas aeruginosa biofilm resistance to hydrogen peroxide and monochloramine. J. Appl. Microbiol. 88, 546-553 (2000).

94 Dingman, J. R., Rayner, M. G., Mishra, S., Zhang, Y., Ehrlich, M. D., Post, J. C. \& Ehrlich, G. D. Correlation between presence of viable bacteria and presence of endotoxin in middle-ear effusions. J. Clin. Microbiol. 36, 3417-3419 (1998).

95 Hall-Stoodley, L., Hu, F. Z., Gieseke, A., Nistico, L., Nguyen, D., Hayes, J., Forbes M., Greenberg, D. P., Dice, B., Burrows, A., Wackym, P. A., Stoodley, P., Post, J. C., Ehrlich, G. D. \& Kerschner, J. E. Direct detection of bacterial biofilms on the middle-ear mucosa of children with chronic otitis media. J. Am. Med. Assoc. 296 202-211 (2006).

96 Lamont, R. J. \& Jenkinson, H. F. Life below the gum line: pathogenic mechanisms of Porphyromonas gingivalis. Microbiol. Mol. Biol. Rev. 62, 1244 (1998). 
97 Anderson, G. G., Palermo, J. J., Schilling, J. D., Roth, R., Heuser, J. \& Hultgren, S. J. Intracellular bacterial biofilm-like pods in urinary tract infections. Science $\mathbf{3 0 1}$, 105-107 (2003).

98 Bayer, A. S., Bolger, A. F., Taubert, K. A., Wilson, W., Steckelberg, J., Karchmer, A. W., Levison, M., Chambers, H. F., Dajani, A. S., Gewitz, M. H., Newburger, J. W., Gerber, M. A., Shulman, S. T., Pallasch, T. J., Gage, T. W. \& Ferrieri, P. Diagnosis and management of infective endocarditis and its complications. Circulation 98, 2936-2948 (1998).

99 Domingue, Sr G. J. \& Hellstrom, W. J. G. Prostatitis. Clin. Microbiol. Rev. 11, 604 (1998).

100 Nishimura, S., Tsurumoto, T., Yonekura, A., Adachi, K. \& Shindo, H. Antimicrobial susceptibility of Staphylococcus aureus and Staphylococcus epidermidis biofilms isolated from infected total hip arthroplasty cases. J. Orthop. Sci. 11, 46-50 (2006).

101 Ceri, H., Olson, M. E., Stremick, C., Read, R. R., Morck, D. \& Buret, A. The Calgary Biofilm Device: new technology for rapid determination of antibiotic susceptibilities of bacterial biofilms. J. Clin. Microbiol. 37, 1771-1776 (1999).

102 Williams, I., Venables, W. A., Lloyd, D., Paul, F. \& Critchley, I. The effects of adherence to silicone surfaces on antibiotic susceptibility in Staphylococcus aureus. Microbiology 143, 2407 (1997)

103 Hoyle, B. D., Wong, C. K. W. \& Costerton, J. W. Disparate efficacy of tobramycin on $\mathrm{Ca} 2+-, \mathrm{Mg} 2+-$, and HEPES-treated Pseudomonas aeruginosa biofilms. Can. J. Microbiol. 38, 1214-1218 (1992).

104 Duguid, I. G., Evans, E., Brown, M. R. W. \& Gilbert, P. Effect of biofilm culture upon the susceptibility of Staphylococcus epidermidis to tobramycin. J. Antimicrob. Chemother. 30, 803 (1992).

105 Tresse, O., Jouenne, T. \& Junter, G. A. The role of oxygen limitation in the resistance of agar-entrapped, sessile-like Escherichia coli to aminoglycoside and -lactam antibiotics. J. Antimicrob. Chemother 36, 521 (1995).

106 Duguid, I. G., Evans, E., Brown, M. R. W. \& Gilbert, P. Growth-rate-independent killing by ciprofloxacin of biofilm-derived Staphylococcus epidermidis evidence for cell-cycle dependency. J. Antimicrob. Chemother. 30, 791 (1992).

107 Christensen, B. B., Sternberg, C., Andersen, J. B., Eberl, L., Moller, S., Givskov, M. \& Molin, S. Establishment of new genetic traits in a microbial biofilm community. Appl. Environ. Microbiol. 64, 2247-2255 (1998)

108 Sutherland, I. W. The biofilm matrix-an immobilized but dynamic microbial environment. Trends Micorbiol. 9, 222-227 (2001)

109 Ghigo, J. M. Natural conjugative plasmids induce bacterial biofilm development. Nature 412, 442-445 (2001).

110 Ehlers, L. J. \& Bouwer, E. J. RP4 plasmid transfer among species of Pseudomonas in a biofilm reactor. Water Sci. Technol. 39, 163-171 (1999).

111 Chen, L. \& Wen, Y. The role of bacterial biofilm in persistent infections and control strategies. Int. J. Oral Sci. 3, 66 (2011).

112 Nobbs, A. H., Lamont, R. J. \& Jenkinson, H. F. Streptococcus adherence and colonization. Microbiol. Mol. Biol. Rev. 73, 407 (2009).

113 Tojo, M., Yamashita, N., Goldmann, D. A. \& Pier, G. B. Isolation and characterization of a capsular polysaccharide adhesin from Staphylococcus epidermidis. J. Infect. Dis. 157, 713 (1988)

114 Zhang, Y. Q., Ren, S. X., Li, H. L., Wang, Y. X., Fu, G., Yang, J., Qin, Z. Q., Miao, Y. G., Wang, W. Y., Chen, R. S., Shen, Y., Chen, Z., Yuan, Z. H., Zhao, G. P., Qu, D., Danchin, A. \& Wen, Y. M. Genome based analysis of virulence genes in a non biofilm forming Staphylococcus epidermidis strain (ATCC 12228). Mol. Microbiol. 49, 1577-1593 (2003).

115 Russell, M. W., Bergmeier, L. A., Zanders, E. D. \& Lehner, T. Protein antigens of Streptococcus mutans: purification and properties of a double antigen and its protease-resistant component. Infect. Immun. 28, 486 (1980).

116 Banas, J. A. \& Vickerman, M. M. Glucan-binding proteins of the oral streptococci. Crit. Rev. Oral Biol. Med. 14, 89 (2003).

117 Kolenbrander, P. E., Ganeshkumar, N., Cassels, F. J. \& Hughes, C. V. Coaggregation: specific adherence among human oral plaque bacteria. FASEB J 7 , 406-413 (1993)

118 Sanchez, C. J., Shivshankar, P., Stol, K., Trakhtenbroit, S., Sullam, P. M., Sauer, K., Hermans, P. W. M. \& Orihuela, C. J. The pneumococcal serine-rich repeat protein is an intra-species bacterial adhesin that promotes bacterial aggregation in vivo and in biofilms. PLoS Pathog. 6, e1001044 (2010).

119 Krämer, R. \& Jung, K. in Bacterial Signaling (eds Heilmann, C. \& Götz, F.) 7-22 (Wiley-VCH Verlag GmbH \& Co. KGaA, Weinheim, 2010).

120 Hall-Stoodley, L., Nistico, L., Sambanthamoorthy, K., Dice, B., Nguyen, D., Mershon, W. J., Johnson, C., Hu, F. Z., Stoodley, P., Ehrlich, G. D. \& Post, J. C. Characterization of biofilm matrix, degradation by DNase treatment and evidence of capsule down regulation in Streptococcus pneumoniae clinical isolates. BMC Microbiol. 8, 173 (2008).

121 Allesen Holm, M., Barken, K. B., Yang, L., Klausen, M., Webb, J. S., Kjelleberg, S. Molin, S., Givskov, M. \& Tolker-Nielsen, T. A characterization of DNA release in Pseudomonas aeruginosa cultures and biofilms. Mol. Microbiol. 59, 1114-1128 (2006).

122 Thomas, V. C., Thurlow, L. R., Boyle, D. \& Hancock, L. E. Regulation of autolysisdependent extracellular DNA release by Enterococcus faecalis extracellular proteases influences biofilm development. J. Bacteriol. 190, 5690 (2008).

123 Rice, K. C., Mann, E. E., Endres, J. L., Weiss, E. C., Cassat, J. E., Smeltzer, M. S. \& Bayles, K. W. The cidA murein hydrolase regulator contributes to DNA release and biofilm development in Staphylococcus aureus. Proc. Natl. Acad. Sci. USA 104, $8113-8118$ (2007)

124 Waters, C. M. \& Bassler, B. L. Quorum sensing: cell-to-cell communication in bacteria. Annu. Rev. Cell Dev. Biol. 21, 319-346 (2005)
125 Eberi, L. N-acyl homoserinelactone-mediated gene regulation in gram-negative bacteria. Syst. Appl. Microbiol. 22, 493-506 (1999).

126 Miller, M. B. \& Bassler, B. L. Quorum sensing in bacteria. Annu. Rev. Microbiol. 55 165-199 (2001).

127 Chu, F., Kearns, D. B., McLoon, A., Chai, Y., Kolter, R. \& Losick, R. A novel regulatory protein governing biofilm formation in Bacillus subtilis. Mol. Microbiol. 68, 1117-1127 (2008)

128 Heilmann, C., Schweitzer, O., Gerke, C., Vanittanakom, N., Mack, D. \& Gotz, F. Molecular basis of intercellular adhesion in the biofilm forming Staphylococcus epidermidis. Mol. Microbiol. 20, 1083-1091 (1996).

129 Rupp, M. E., UIphani, J. S., Fey, P. D. \& Mack, D. Characterization of Staphylococcus epidermidis polysaccharide intercellular adhesin/hemagglutinin in the pathogenesis of intravascular catheter-associated infection in a rat model. Infect. Immun. 67, 2656 (1999)

130 Kristian, S. A., Golda, T., Ferracin, F., Cramton, S. E., Neumeister, B., Peschel, A., Gotz, F. \& Landmann, R. The ability of biofilm formation does not influence virulence of Staphylococcus aureus and host response in a mouse tissue cage infection model. Microb. Pathogenesis 36, 237-245 (2004).

131 Ziebuhr, W., Heilmann, C., Gotz, F., Meyer, P., Wilms, K., Straube, E. \& Hacker, J. Detection of the intercellular adhesion gene cluster (ica) and phase variation in Staphylococcus epidermidis blood culture strains and mucosal isolates. Infect. Immun. 65, 890-896 (1997).

132 Vuong, C., Gotz, F. \& Otto, M. Construction and characterization of an agr deletion mutant of Staphylococcus epidermidis. Infect. Immun. 68, 1048 (2000)

133 Vuong, C., Saenz, H. L., Götz, F. \& Otto, M. Impact of the agr quorum-sensing system on adherence to polystyrene in Staphylococcus aureus. J. Infect. Dis. 182, 1688 (2000)

134 Vuong, C., Kocianova, S., Yao, Y., Carmody, A. B. \& Otto, M. Increased colonization of indwelling medical devices by quorum-sensing mutants of Staphylococcus epidermidis in vivo. J. Infect. Dis. 190, 1498 (2004).

135 Williams, R. J. \& Govan, J. R. W. Pyocine syping of mucoid strains of Pseudomonas aeruginosa isolated from children with cystic fibrosis. J. Med. Microbiol. 6, 409-412 (1973).

136 Ogle, J. W., Janda, J. M., Woods, D. E. \& Vasil, M. L. Characterization and use of a DNA probe as an epidemiological marker for Pseudomonas aeruginosa. J. Infect. Dis. 155, 119 (1987)

137 Mack, D. Molecular mechanisms of Staphylococcus epidermidis biofilm formation. J. Hosp. Infect. 43, S113-S125 (1999).

138 McCann, M. T., Gilmore, B. F. \& Gorman, S. P. Staphylococcus epidermidis device related infections: pathogenesis and clinical management. J. Pharm. Pharmacol. 60, 1551-1571 (2008)

139 Caiazza, N. C., Merritt, J. H., Brothers, K. M. \& O'Toole, G. A. Inverse regulation of biofilm formation and swarming motility by Pseudomonas aeruginosa PA14. J. Bacteriol. 189, 3603 (2007).

140 Tabak, M., Scher, K., Hartog, E., Romling, U., Matthews, K. R., Chikindas, M. L. \& Yaron, S. Effect of triclosan on Salmonella typhimurium at different growth stages and in biofilms. FEMS Microbiol. Lett. 267, 200-206 (2007).

141 Herrmann, M., Vaudaux, P. E., Pittet, D., Auckenthaler, R., Lew, P. D., SchumacherPerdreau, F., Peters, G. \& Waldvogel, F. A. Fibronectin, fibrinogen, and laminin act as mediators of adherence of clinical Staphylococcal isolates to foreign material. J. Infect. Dis. 158, 693-701 (1988).

142 McGavin, M. H., Krajewska-Pietrasik, D., Ryden, C. \& Hook, M. Identification of a Staphylococcus aureus extracellular matrix-binding protein with broad specificity. Infect. Immun. 61, 2479 (1993).

143 Eberhard, J., Menzel, N., Dommisch, H., Winter, J., Jepsen, S. \& Mutters, R. The stage of native biofilm formation determines the gene expression of human defensin 2, psoriasin, ribonuclease 7 and inflammatory mediators: a novel approach for stimulation of keratinocytes with in situ formed biofilms. Oral Microbiol. Immun. 23, 21-28 (2008).

144 Cierny lii, G. \& DiPasquale, D. Periprosthetic total joint infections: staging, treatment, and outcomes. Clin Orthop. Relat Res. 403, 23 (2002).

145 McPherson, E. J., Woodson, C., Holtom, P., Roidis, N., Shufelt, C. \& Patzakis, M. Periprosthetic total hip infection: outcomes using a staging system. Clin. Orthop. Relat. Res, 403, 8-15 (2002).

146 Kehinde, E. O., Rotimi, V. O., Al-Awadi, K. A., Abdul-Halim, H., Boland, F., AlHunayan, A. \& Pazhoor, A. Factors predisposing to urinary tract infection after J ureteral stent insertion. J. Urol. 167, 1334-1337 (2002).

147 Quirynen, M., Brecx, M. \& Steenberghe, V. D. Biofilms in the Oral Cavity: Impact of Surface Characteristics 167-187 (Harwood Academic Publishers, Amsterdam, 2000).

148 Subramani, K., Jung, R. E., Molenberg, A. \& Hammerle, C. H. Biofilm on dental implants: a review of the literature. Int. J. Oral. Maxillofac. Implants 24, 616 (2009).

149 Ramage, G., Tunney, M. M., Patrick, S., Gorman, S. P. \& Nixon, J. R. Formation of Propionibacterium acnes biofilms on orthopaedic biomaterials and their susceptibility to antimicrobials. Biomaterials 24, 3221-3227 (2003).

150 Teughels, W., Van Assche, N., Sliepen, I. \& Quirynen, M. Effect of materia characteristics and/or surface topography on biofilm development. Clin. Oral Implan. Res 17, 68-81 (2006).

151 Medilanski, E., Kaufmann, K., Wick, L. Y Wanner, O. \& Harms, H. Influence of the surface topography of stainless steel on bacterial adhesion. Biofouling 18, 193-203 (2002)

152 Carlen, A., Nikdel, K. Wennerberg, A., Holmberg, K. \& Olsson, J. Surface characteristics and in vitro biofilm formation on glass ionomer and composite resin. Biomaterials 22, 481-487 (2001). 
153 Allion, A., Baron, J. P. \& Boulange-Petermann, L. Impact of surface energy and roughness on cell distribution and viability. Biofouling 22, 269-278 (2006)

154 Emery, B. E., Dixit, R., Formby, C. C. \& Biedlingmaier, J. F. The resistance of maxillofacial reconstruction plates to biofilm formation in vitro. Laryngoscope 113 1977-1982 (2003)

155 Absolom, D. R., Lamberti, F. V., Policova, Z., Zingg, W., Van Oss, C. J. \& Neumann, A. W. Surface thermodynamics of bacterial adhesion. Appl. Environ. Microbiol. 46, 90-97 (1983)

156 Reid, G., Hawthorn, L. A., Mandatori, R., Cook, R. L. \& Beg, H. S. Adhesion of lactobacilli to polymer surfaces in vivo and in vitro. Microb. Ecol. 16, 241-251 (1988).

157 Reid, G., Lam, D., Policova, Z. \& Neumann, A. W. Adhesion of two uropathogens to silicone and lubricious catheters: influence of $\mathrm{pH}$, urea and creatinine. J. Mater. Sci. Mater. Med 4, 17-22 (1993).

158 Pasmore, M., Todd, P., Smith, S., Baker, D., Silverstein, J., Coons, D. \& Bowman, C. N. Effects of ultrafiltration membrane surface properties on Pseudomonas aeruginosa biofilm initiation for the purpose of reducing biofouling. J. Membr. Sci. 194, 15-32 (2001).

159 Razatos, A., Ong, Y. L., Sharma, M. M. \& Georgiou, G. Molecular determinants of bacterial adhesion monitored by atomic force microscopy. Proc. Natl. Acad. Sci. 95 11059 (1998).

160 Naylor, P. T., Myrvik, Q. N. \& Gristina, A. Antibiotic resistance of biomaterial-adherent coagulase-negative and coagulase-positive staphylococci. Clin. Orthop. Relat. Res. 261, 126 (1990)

161 Webb, L. X., Holman, J., de Araujo, B., Zaccaro, D. J. \& Gordon, E. S. Antibiotic resistance in staphylococci adherent to cortical bone. J. Orthop. Trauma 8, 28 (1994).

162 Hallab, N., Bundy, K., O'Coonor, K., Clark, R. \& Moses, R. Surface charge, biofilm composition and cellular morphology as related to cellular adhesion to biomaterials. Proceedings of the 1995 Fourteenth Southern Biomedical Engineering Conference, pp 81-84.

163 Subbiahdoss, G., Kuijer, R., Busscher, H. J. \& van der Mei, H. C. Mammalian cell growth versus biofilm formation on biomaterial surfaces in an in vitro post-operative contamination model. Microbiology 156, 3073 (2010).

164 Gottenbos, B., Grijpma, D. W., Van Der Mei, H. C., Feijen, J. \& Busscher, H. J. Antimicrobial effects of positively charged surfaces on adhering Gram-positive and Gram-negative bacteria. J. Antimicrob. Chemother. 48, 7 (2001).

165 Nguyen, L. L., Nelson, C. L., Saccente, M., Smeltzer, M. S., Wassell, D. L. \& McLaren, S. G. Detecting bacterial colonization of implanted orthopaedic devices by ultrasonication. Clin. Orthop. Relat. Res 403, 29-37 (2002).

166 Ince, A., Rupp, J., Frommelt, L., Katzer, A., Gille, J. \& Lohr, J. F. Is 'Aseptic' Loosening of the Prosthetic Cup after Total Hip Replacement Due to Nonculturable Bacterial Pathogens in Patients with Low-Grade Infection? Clin. Infect. Dis 39, 1599-1603 (2004).

167 Stoodley, P., Kathju, S., Hu, F. Z., Erdos, G., Levenson, J. E., Mehta, N., Dice, B., Johnson, S., Hall-Stoodley, L., Nistico, L., Sotereanos, N., Sewecke, J., Post, J. C. \& Ehrlich, G. D. Molecular and imaging techniques for bacterial biofilms in joint arthroplasty infections. Clin. Orthop. Relat. Res 437, 31-40 (2005).

168 Sampedro, M. F., Huddleston, P. M., Piper, K. E., Karau, M. J., Dekutoski, M. B., Yaszemski, M. J., Currier, B. L., Mandrekar, J. N., Osmon, D. R., McDowell, A Patrick, S, Steckelberg, J. M. \& Patel, R A biofilm approach to detect bacteria on removed spinal implants. Spine 35, 1218-1224 (2010).

169 Piper, K. E., Sampedro, M. F., Steckelberg, K. E., Mandrekar, J. N., Karau, M. J, Steckelberg, J. M., Berbari, E. F., Osmon, D. R., Hanssen, A. D., Lewallen, D. G., Cofield, R. H., Sperling, J. W., Sotelo, J. S., Huddleston, P. M., Dekutoski, M. B. Yaszemski, M., Currier, B. \& Patel, R. C-reactive protein, erythrocyte sedimentation rate and orthopedic implant infection. PLoS One 5, e9358 (2010).

170 Panda, R. K., Malaviya, A. N., Sampathkumar, A., Iyer, K. S., Das, B., Sharma, M. L. \& Venugopal, P. Serial estimation of C-reactive protein following cardiac surgery. Indian J. Thorac. Cardiovas. Surg. 5, 18-23 (1987).

171 Bottner, F., Wegner, A., Winkelmann, W., Becker, K., Erren, M. \& Gotze, C. Interleukin-6, procalcitonin and TNF-\{alpha\}: markers of peri-prosthetic infection following total joint replacement. J. Bone Joint Surg. Br 89, 94-99 (2007).

172 Schiesser, M., Stumpe, K. D. M., Trentz, O., Kossmann, T. \& von Schulthess, G. K. Detection of Metallic Implant-associated Infections with FDG PET in Patients with Trauma: Correlation with Microbiologic Results1. Radiology 226, 391 (2003).

173 Meffert, R. M. Maintenance and treatment of the ailing and failing implant. J. Indiana Dent. Assoc. 73, 22 (1994).

174 Jovanovic, S. A. The management of peri-implant breakdown around functioning osseointegrated dental implants. J. Periodont. 64, 1176 (1993).

175 Shirtliff, M. \& Leid, J. in Biofilm Formation on Natural Teeth and Dental Implants What is the Difference? Vol. 3 (eds. Armellini, D., Reynolds, M. A., Harro, J. M. \& Molly, L. ) 109-122 (Springer, Maryland, 2009).

176 Falahee, M. H., Matthews, L. S. \& Kaufer, H. Resection arthroplasty as a salvage procedure for a knee with infection after a total arthroplasty. J. Bone Joint Surg. Am 69, 1013 (1987).

177 Tsukayama, D. T., Estrada, R. \& Gustilo, R. B. Infection after total hip arthroplasty: study of the treatment of one hundred and six infections. J. Bone Joint Surg. Am. 78, 512-523 (1996).

178 Hanssen, A. D., Rand, J. A. \& Osmon, D. R. Treatment of the infected total knee arthroplasty with insertion of another prosthesis: the effect of antibiotic-impregnated bone cement. Clin. Orthop. Relat. Res. 309, 44 (1994).
179 Duncan, C. P. \& Beauchamp, C. A temporary antibiotic-loaded joint replacement system for management of complex infections involving the hip. Orthop. Clin. North Am. 24, 751 (1993).

180 Masri, B. A., Duncan, C. P. \& Beauchamp, C.P. Long-term elution of antibiotics from bone-cement: an in vivo study using the prosthesis of antibiotic-loaded acrylic cement (PROSTALAC) system. J. Arthroplasty 13, 331-338 (1998).

181 Trebse, R., Pisot, V. \& Trampuz, A. Treatment of infected retained implants. J. Bone Joint Surg. Br. 87, 249 (2005)

182 Bergamini, T. M., Peyton, J. C. \& Cheadle, W. G. Prophylactic antibiotics prevent bacterial biofilm graft infection. J. Surg. Res. 52, 101-105 (1992).

183 Kwaan, J. H. M. \& Connolly, J. E. Successful management of prosthetic graft infection with continuous povidone-iodine irrigation. Arch. Surg. 116, 716 (1981).

184 Kehinde, E. O., Rotimi, V. O., Al-Hunayan, A., Abdul-Halim, H., Boland, F. \& Al-Awadi, K. A. Bacteriology of urinary tract infection associated with indwelling J ureteral stents. J. Endourol. 18, 891-896 (2004).

185 Balaban, N. Q., Merrin, J., Chait, R., Kowalik, L. \& Leibler, S. Bacterial persistence as a phenotypic switch. Science 305, 1622 (2004).

186 Brackman, G., Hillaert, U., Van Calenbergh, S., Nelis, H. J. \& Coenye, T. Use of quorum sensing inhibitors to interfere with biofilm formation and development in Burkholderia multivorans and Burkholderia cenocepacia. Res. Microbiol. 160, 144-151 (2009).

187 Kociolek, M. G. Quorum-sensing inhibitors and biofilms. Curr. Med. Chem.: AntiInfect. Agents 8, 315-326 (2009).

188 Givskov, M., de Nys, R., Manefield, M., Gram, L., Maximilien, R., Eberl, L., Molin, S. Steinberg, P. D. \& Kjelleberg, S. Eukaryotic interference with homoserine lactonemediated prokaryotic signalling. J. Bacteriol. 178, 6618-6622 (1996).

189 Eberl, L., Christiansen, G., Molin, S. \& Givskov, M. Differentiation of Serratia liquefaciens into swarm cells is controlled by the expression of the flhD master operon. J. Bacteriol. 178, 554 (1996)

190 Rasmussen, T. B., Manefield, M., Andersen, J. B., Eberl, L., Anthoni, U., Christophersen, C., Steinberg, P., Kjelleberg, S. \& Givskov, M. How Delisea pulchra furanones affect quorum sensing and swarming motility in Serratia liquefaciens MG1. Microbiology 146, 3237-3244 (2000)

191 Persson, T., Hansen, T. H., Rasmussen, T. B., Skinderso, M. E., Givskov, M. \& Nielsen, J. Rational design and synthesis of new quorum-sensing inhibitors derived from acylated homoserine lactones and natural products from garlic. Org. Biomol. Chem. 3, 253-262 (2004).

192 Reverchon, S., Chantegrel, B., Deshayes, C., Doutheau, A. \& Cotte-Pattat, N. New synthetic analogues of $\mathrm{N}$-acyl homoserine lactones as agonists or antagonists of transcriptional regulators involved in bacterial quorum sensing. Bioorg. Medicinal Chem. Lett. 12, 1153-1157 (2002).

193 Darouiche, R. O. Device-associated infections: a macroproblem that starts with microadherence. Clin. Infect. Dis. 33, 1567-1572 (2001).

194 Reid, G. Applications from bacterial adhesion and biofilm studies in relation to urogenital tissues and biomaterials: a review. J. Ind. Microbiol. Biotechnol. 13, 90-96 (1994).

195 Wizemann, T. M., Adamou, J. E. \& Langermann, S. Adhesins as targets for vaccine development. Emerg. Infect. Dis. 5, 395 (1999).

196 Palaszynski, S., Pinkner, J., Leath, S., Barren, P, Auguste, C. G., Burlein, J., Hultgren, S. \& Langermann, S. Systemic immunization with conserved pilus-associated adhesins protects against mucosal infections. Dev. Biol. Stand. 92, 117-122 (1998).

197 Chung K. K. Schumacher, J. F. Sampson, E. M., Burne, R. A. Antonelli, P.J \& Brennan, A. B. Impact of engineered surface microtopography on biofilm formation of Staphylococcus aureus. Biointerphases 2, 89-94 (2007).

198 Hetrick, E. M. \& Schoenfisch, M. H. Reducing implant-related infections: active release strategies. Chem. Soc. Rev. 35, 780-789 (2006).

199 Charville, G. W., Hetrick, E. M., Geer, C. B. \& Schoenfisch, M. H. Reduced bacteria adhesion to fibrinogen-coated substrates via nitric oxide release. Biomaterials 29 4039-4044 (2008).

200 Ovaska, M., Lindahl, J., Makinen, T., Madanat, R., Pulliainen, L., Kiljunen, V., Hirvensalo, E. \& Tukiainen, E. [Postoperative infection-removal of screws and plates?]. Suomen Ortopedia ja Traumatologia 4, 34-36 (2011).

201 Hawthorn, L. A. \& Reid, G Exclusion of uropathogen adhesion to polymer surfaces by Lactobacillus acidophilus. J. Biomed. Mater. Res. 24, 39-46 (1990).

202 Darouiche, R. O., Donovan, W. H., Del Terzo, M., Thornby, J. I., Rudy, D. C. \& Hull, R. A. Pilot trial of bacterial interference for preventing urinary tract infection. Urology 58, 339-344 (2001).

203 Yoshinari, M., Kato, T., Matsuzaka, K., Hayakawa, T. \& Shiba, K. Prevention of biofilm formation on titanium surfaces modified with conjugated molecules comprised of antimicrobial and titanium-binding peptides. Biofouling 26, 103-110 (2009).

204 Curtin, J. J. \& Donlan, R. M. Using bacteriophages to reduce formation of catheterassociated biofilms by Staphylococcus epidermidis. Antimicrob. Agents Chemother 50, 1268 (2006).

205 DiTizio, V., Ferguson, G. W., Mittelman, M. W., Khoury, A. E., Bruce, A. W. \& DiCosmo, F. A liposomal hydrogel for the prevention of bacterial adhesion to catheters. Biomaterials 19, 1877-1884 (1998).

206 Taylor, E. N. \& Webster, T. J. The use of superparamagnetic nanoparticles for prosthetic biofilm prevention. Int. J. Nanomed 4, 145 (2009).

207 Rittmann, B. E. \& McCarty, P. L. Model of steady state biofilm kinetics. Biotechnol. Bioeng. 22, 2343-2357 (1980). 
208 Wanner, O. \& Gujer, W. A multispecies biofilm model. Biotechnol. Bioeng. 28, 314-328 (1986).

209 Cogan, N. G. \& Keener, J. P. The role of the biofilm matrix in structural development. Math. Med. Biol. 21, 147 (2004).

210 Eberl, H. J. \& Collinson, S. Theoretical biology and medical modelling. Theor. Biol. Med. Model 6, 30 (2009).

211 Kreft, J. U. \& Wimpenny, J. W. T. Effect of EPS on biofilm structure and function as revealed by an individual-based model of biofilm growth. Water Sci. Technol 43, 135-142 (2001).

212 Eberl, H. J., Khassehkhan, H. \& Demaret, L. A mixed-culture model of a probiotic biofilm control system. Comput. Math. Met. Med. 11, 99-118 (2010).

213 Klapper, I., Rupp, C. J., Cargo, R., Purvedorj, B. \& Stoodley, P. Viscoelastic fluid description of bacterial biofilm material properties. Biotechnol. Bioeng. 80, 289-296 (2002).

214 Elliott, T. S. J., Moss, H. A., Tebbs, S. E., Wilson, I. C., Bonser, R. S., Graham, T. R., Burke, L. P. \& Faroqui, M. H. Novel approach to investigate a source of microbial contamination of central venous catheters. Eur. J. Clin. Microbiol. Infect. Dis. 16, 210-213 (1997).

215 Guo, B., Zhao, X., Shi, Y., Zhu, D. \& Zhang, Y. Pathogenic implication of a fibrinogenbinding protein of Staphylococcus epidermidis in a rat model of intravascularcatheter-associated infection. Infect. Immun. 75, 2991 (2007).

216 Schwab, S. J. \& Beathard, G. The hemodialysis catheter conundrum: Hate living with them, but can't live without them. Kidney Int. 56, 1-17 (1999)

217 Rello, J., Coll, P., Net, A. \& Prats, G. Infection of pulmonary artery catheters. Epidemiologic characteristics and multivariate analysis of risk factors. Chest 103, 132 (1993).

218 Bonner, M. C., Tunney, M. M., Jones, D. S. \& Gorman, S. P. Factors affecting in vitro adherence of ureteral stent biofilm isolates to polyurethane. Int. J. Pharm. 151, 201-207 (1997).

219 Read, R. R., Eberwein, P., Dasgupta, M. K., Grant, S. K., Lam, K., Nickel, J. C. \& Costerton, J. W. Peritonitis in peritoneal dialysis: bacterial colonization by biofilm spread along the catheter surface. Kidney Int. 35, 614-621 (1989).

220 Hurrell, E., Kucerova, E., Loughlin, M., Caubilla-Barron, J. \& Forsythe, S. J. Biofilm formation on enteral feeding tubes by Cronobacter sakazakii, Salmonella serovars and other Enterobacteriaceae. Int. J. Food Microbiol. 136, 227-231 (2009).

221 DeLegge, R. L. \& DeLegge, M. H. Percutaneous endoscopic gastrostomy evaluation of device materials: are we 'Failsafe'? Nutr. Clin. Pract. 20, 613 (2005).

222 O’May, G. A., Reynolds, N., Smith, A. R., Kennedy, A. \& Macfarlane, G. T. Effect of $\mathrm{pH}$ and antibiotics on microbial overgrowth in the stomachs and duodena of patients undergoing percutaneous endoscopic gastrostomy feeding. J. Clin. Microbiol. 43 3059 (2005)

223 Lai, H. C., Juang, S. E., Liu, T. J. \& Ho, W. M. Fires of endotracheal tubes of three different materials during carbon dioxide laser surgery. Acta. Anaesthesiol. Sin. 40, 47 (2002).

224 Perkins, S. D., Woeltje, K. F. \& Angenent, L. T. Endotracheal tube biofilm inoculation of oral flora and subsequent colonization of opportunistic pathogens. Int. J. Med. Microbiol. 300, 503-511 (2010).

225 Bjorling, G., Axelsson, S., Johansson, U. B., Lysdahl, M., Markstrom, A., Schedin, U., Aune, R. E., Frostell, C. \& Karlsson, S. Clinical use and material wear of polymeric tracheostomy tubes. Laryngoscope 117, 1552-1559 (2007).

226 Meslemani, D., Yaremchuk, K. \& Rontal, M. Presence of biofilm on adult tracheostomy tubes. Ear Nose Throat J. 89, 496 (2010).

227 Barker-Davies, R. M., Freeman, B. J. C., Bayston, R. \& Ashraf, W. Spinal implant materials: attachment and biofilm production by propionibacterium acnes and subsequent effect of exposure to antibiotics. J. Bone Joint Surg. Br. Proc. 88, 391 (2006).
228 Rajpurkar, A., Shah, R., Starkman, J. \& Dhabuwala, C. B. Tissue ingrowth in penile implants and its effect on repeat penile surgery. Int. J. Impot. Res. 16, 203-206 (2004).

229 Silverstein, A. D., Henry, G. D., Evans, B., Pasmore, M., Simmons, C. J. \& Donatucci, C. F. Biofilm formation on clinically non infected penile prostheses. J. Urol. 176, 1008-1011 (2006)

230 Dunn, K. W., Hall, P. N. \& Khoo, C. T. K. Breast implant materials: sense and safety. Brit. J. Plast. Surg. 45, 315-321 (1992).

231 Netscher, D. T., Weizer, G., Wigoda, P., Walker, L. E., Thornby, J. \& Bowen, D. Clinical relevance of positive breast periprosthetic cultures without overt infection. Plast. Reconstr. Surg. 96, 1125-1129 (1995).

232 Bono, J. V. \& Scott, R. D. Revision Total Knee Arthroplasty (Springer Verlag, New York, 2005).

233 Sokoloff, L. The Joints and Synovial Fluid (Academic Press, New York, 1978)

234 Al-Maiyah, M., Hill, D., Bajwa, A., Slater, S., Patil, P., Port, A. \& Gregg, P. J. Bacterial contaminants and antibiotic prophylaxis in total hip arthroplasty. J. Bone Joint Surg. $\mathrm{Br}$ 87, 1256-1258 (2005).

235 Zembic, A., Sailer, I., Jung, R. E. \& Hämmerle, C. H. F. Randomized controlled clinical trial of customized zirconia and titanium implant abutments for single tooth implants in canine and posterior regions: 3 year results. Clin. Oral Implan. Res 20, 802-808 (2009).

236 Elter, C., Heuer, W., Demling, A., Hannig, M., Heidenblut, T. \& Stiesch, M. Comparative analysis of biofilm formation on dental implant abutments with respect to supra-and subgingival areas: polytetrafluoroethylene versus titanium. Int. J. Prosthodont. 24, 373-375 (2011).

237 Gil, F. J., Aparicio, C., Manero, J. M. \& Padrós, A. Influence of the height of the external hexagon and surface treatment on fatigue life of commercially pure titanium dental implants. Int J Oral Maxillofac Implants 24, 583 (2009).

238 Agostinho, A., James, G., Wazni, O., Citron, M. \& Wilkoff, B. D. Inhibition of Staphylococcus aureus biofilms by a novel antibacterial envelope for use with implantable cardiac devices. Clin. Transl. Sci. 2, 193-198 (2009).

239 Yu, J. L., Andersson, R. \& Ljungh, A. Protein adsorption and bacterial adhesion to biliary stent materials. J. Surg. Res. 62, 69-73 (1996).

240 Pruthi, V., Al-Janabi, A. \& Pereira, B. J. Characterization of biofilm formed on intrauterine devices. Indian J. Med. Microbiol. 21, 161 (2003).

241 Nair, K., Muraleedharan, C. V. \& Bhuvaneshwar, G. S. Developments in mechanical heart valve prosthesis. Sadhana 28, 575-587 (2003).

242 Park, J. B. \& Bronzino, J. D. in Metallic Biomaterials (eds Park, J. B. \& Kim, Y. K.) (CRC Press, Boca Raton, 2003).

243 Ratner, B. D., Hoffman, A. S., Schoen, F. J. \& Lemons, J. E in Metals (ed. Brunski, J. B. ) 137-153 (Elsevier Academic Press, San Diego, 2004).

244 Mani, G., Feldman, M. D., Patel, D. \& Agrawal, C. Coronary stents: a materials perspective. Biomaterials 28, 1689-1710 (2007).

245 Shimizu, K., Kobayakawa, S., Tsuji, A. \& Tochikubo, T. Biofilm formation on hydrophilic intraocular lens material. Curr. Eye Res. 31, 989-997 (2006).

246 Okajima, Y., Kobayakawa, S., Tsuji, A. \& Tochikubo, T. Biofilm formation by Staphylococcus epidermidis on intraocular lens material. Invest. Ophthalmol. Vis. Sci. 47, 2971 (2006)

247 Bayston, R., Vera, L. \& Ashraf, W. Activity of an Antimicrobial Hydrocephalus Shunt Catheter against Propionibacterium acnes. Antimicrob. Agents Chemother. 54, 5082 (2010).

248 Kettle, C. \& Johanson, R. B. Absorbable synthetic versus catgut suture material for perineal repair. Cochrane Database Syst. Rev. 2, CD000006 (2000).

249 Henry-Stanley, M. J., Hess, D. J., Barnes, A. M. T., Dunny, G. M. \& Wells, C. L. Bacterial Contamination of Surgical Suture Resembles a Biofilm. Surg. Infect. 11, 433-439 (2010).

250 Kathju, S., Nistico, L., Hall-Stoodley, L., Post, J. C., Ehrlich, G. D. \& Stoodley, P. Chronic surgical site infection due to suture-associated polymicrobial biofilm. Surg. Infect. 10, 457-461 (2009). 


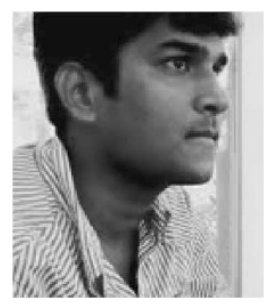

Venkatesan Nandakumar is a research scholar at the Department of Biotechnology, IIT Madras, Chennai-600036, India. E-mail: nandooniran@gmail.com. He holds an M. Tech degree in Biotechnology from Vellore Institute of Technology, Vellore, India. He has authored four technical papers. His area of interest includes biomaterials and tissue engineering.

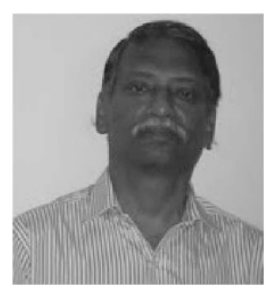

Samuel Chittaranjan is a senior consultant in Orthopedics at MIMS, Calicut, India. He was a Professor in the Department of Orthopedics at CMC, Vellore, India, from 1995 to 2011. He is a surgeon and has special interest in joint replacement surgery of knee and hip, arthroscopic and trauma surgery. His areas of interest include cartilage regeneration.

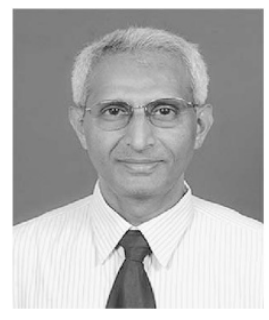

Dr Valikapathalil Mathew Kurian is a cardiovascular and thoracic surgeon with 25 years of experience in the field. He is specialized in surgery for acquired heart disease including coronary revascularization, heart valve surgery and aortic surgery. He is actively involved in clinical research, preclinical trials and device development. He has developed a new mechanical heart valve, which has successfully completed the preclinical trials.

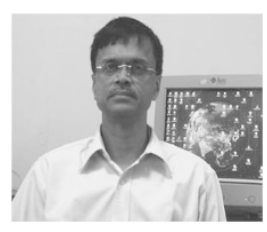

Mukesh Doble is a Professor and Head of the Department of Biotechnology at IIT Madras, Chennai-600036, India (Tel: + 91-4422574107, E-mail: mukeshd@iitm.ac.in; mukes.doble0@gmail.com; http://www.biotech.iitm.ac.in/doble_research). He has previously worked for 20 years in Imperial Chemical Industries (ICI) and General Electric (GE) Technology centres. His areas of interest are drug design, biomaterials, bioreactors and bioremediation. He holds B. Tech and M. Tech degrees in Chemical Engineering from IIT, Madras, India, and a PhD from University of Aston, Birmingham, UK, and postdoctoral at University of Cambridge, UK, and Texas A\&M, USA. He has authored or coauthored 190 technical papers, six books including Drug Design, Basics and Applications, Tata McGraw Hill Education; Green Chemistry and processes, Elsevier; Biochemical Engineering, Prentice Hall Publications; Biotreatment of industrial effluents, Elsevier; Biotransformations \& Bioprocesses, Marcell Dekker, New york; and Homogeneous catalysis: Mechnanisms \& industrial applications., John Wiley \& sons, and filed four patents. He is a fellow of Royal Society of Chemistry, London, and a recipient of Herdillia Award for 'Excellence in Basic Research' from Indian Institute of Chemical Engineers. He is in the editorial board of the journal CHEMICAL ENGINEERING (McGraw Hill Publications) and a member of the American and Indian Institute of Chemical engineers. 